\title{
Structural and Electrical Properties of Zn1-xCrxO NTCR Nanoceramics Synthesized by High Energy Ball Milling
}

\section{Bikram Keshari Das}

Kalinga Institute of Social Sciences(KISS),Deemed to be University,Bhubaneswar

\section{Tanushree Das}

Kalinga Institute of Social Sciences

\section{Kajal Parashar}

KIITS University: Kalinga Institute of Industrial Technology

S.K.S Parashar ( $\nabla$ sksparashar@yahoo.com )

KIIT University https://orcid.org/0000-0001-8739-7765

\section{Rajeev Kumar}

IISC Bangalore: Indian Institute of Science

Anupama . A. V

IISC Bangalore: Indian Institute of Science

\section{Balaram Sahoo}

IISC Bangalore: Indian Institute of Science

\section{Research Article}

Keywords: Cr doped ZnO, HEBM, Rietveld refinement, SEM, NTCR behaviour

Posted Date: February 23rd, 2021

DOl: https://doi.org/10.21203/rs.3.rs-221973/v1

License: (a) This work is licensed under a Creative Commons Attribution 4.0 International License. Read Full License 


\title{
Structural and electrical properties of $\mathrm{Zn}_{1-\mathrm{x}} \mathrm{Cr}_{\mathrm{x}} \mathrm{O}$ NTCR nanoceramics synthesized by high energy ball milling
}

\author{
Bikram Keshari Das $^{1 *}$, Tanushree Das ${ }^{1}$, Kajal Parashar $^{2}$, S. K. S. Parashar ${ }^{2, *}$, Rajeev Kumar ${ }^{3}$, Anupama A. V. ${ }^{3}$, \\ Balaram $\mathrm{Sahoo}^{3}$ \\ ${ }^{1}$ Department of Chemistry, Nano centre of Excellence, Kalinga Institute of Social Sciences (KISS) Deemed to \\ be University, Bhubaneswar-751024, Odisha, India \\ ${ }^{2}$ School of Applied Sciences, Nano Sensor Lab, KIIT University, Bhubaneswar-751024, Odisha, India \\ ${ }^{3}$ Materials Research Centre, Indian Institute of Science, Bangalore-560012, India
}

\begin{abstract}
$\mathrm{Cr}$ doped $\mathrm{ZnO}(\mathrm{x}=0-0.04)$ nanoceramics was successfully synthesized by high energy ball milling (HEBM) technique. The structural and electrical properties of the synthesized sample has been studied in detail. The doping of $\mathrm{Cr}$ into $\mathrm{ZnO}$ has been verified by $\mathrm{X}$-ray diffraction (XRD) and also from the variation in structural parameters. Rietveld refinement XRD pattern of calcined sample showed the hexagonal wurtzite structure and it did not induce impurity phases. From the XRD, it has been confirm that maximum result confirms that up to 4 atomic\% of $\mathrm{Cr}$ can be doped into $\mathrm{ZnO}$. The strain of the sample reduced with increase in particle size. After sintering, there is a growth of particle size of $\mathrm{Cr}$ doped $\mathrm{ZnO}$ sample. The impedance spectroscopy data shows a single semicircle in the high frequency region corresponding to the bulk properties of the nanoceramic sample. The decrease in real part of the impedance with temperature suggests the NTCR behavior of the sample in the temperature range of 300-500 ${ }^{\circ} \mathrm{C}$. The temperature dependent relaxation phenomena are also observed for the synthesized ceramic sample at high temperature. Distributed relaxation time suggests that the relaxation in the synthesized samples is of non-Debye type. The equivalent electrical circuit of the semicircular pattern in the impedance spectrum of $\mathrm{ZnO}$ and $\mathrm{Zn}_{1-\mathrm{x}} \mathrm{Cr}_{\mathrm{x}} \mathrm{O}$ nanoceramics sample is a parallel combination of bulk resistance $\left(\mathrm{R}_{\mathrm{b}}\right)$ and bulk capacitance $\left(\mathrm{C}_{\mathrm{b}}\right)$.
\end{abstract}

Keywords: Cr doped ZnO; HEBM; Rietveld refinement; SEM; NTCR behaviour.

*Corresponding author: S. K. S. Parashar (sksparashar@yahoo.com)

Bikram Keshari Das (bikram.das@kiss.ac.in) 


\section{Introduction}

Temperature sensors are used in domestic and industrial sector, laboratory and medical processes to regulate the temperature. The electrical behaviour of NTC ceramic depends on factors such as purity, composition, cation distribution [1]. The distribution of cation and oxygen parameter (u), gives information to build up physical properties for application in industry [2]. Nano metal oxide has paying attention of scientific community because of their unique properties like electronic properties, optical properties and large surface to volume ratio. The properties of a materials depend on particle size, crystalline structure, their surface conditions and shape [3]. Different behaviour of metal oxides such as $\mathrm{ZnO}, \quad \mathrm{In}_{2} \mathrm{O}_{3}, \mathrm{CdO}, \mathrm{CuO}$ and $\mathrm{SnO}_{2}$ have been extensively investigated in doped and undoped form[4-6]. $\mathrm{ZnO}$ is an important semiconductor material among different transition metal oxides[7], it has a with wide band gap of $\sim 3.37 \mathrm{eV}$, large exciton binding energy of $\sim 60$ meV having hexagonal wurtzite structure and belong to the space group $P 6_{3} m c\left(\mathrm{C}_{6} \mathrm{~V}\right)$ [8]. Because of its unique properties like non-toxic nature, abundance in nature, low cost, suitability for doping, high thermal and chemical stability and is an important semiconductor materials [9]. $\mathrm{ZnO}$ has versatile applications like UV photodetectors [10] gas sensors [11], solar cells [12], spintronics [13] luminescent materials [14], piezoelectric devices [15], light emitting devices [16], Thermistor [17] and cancer treatment [18]. Optical, electrical and other material properties of $\mathrm{ZnO}$ can be enhanced and control for its practical applications by doping with selective elements [19]. From the literature, it is found that doping with metal ions makes suitable for specific needs [7]. Several synthesis method has been used to synthesis doped and undoped $\mathrm{ZnO}$ nanoparticles such as sol-gel [20], solid state [21], hydrothermal [22] ball milling [23], microwave method [24], sonochemical method [25] etc.

Among these methods, ball milling is superior one because it reduces the phase transition temperature, sintering temperature, increases the particle reactivity. Particle size can be easily decreased to nano scale level and also low temperature solubility limit can be extended [26]. The sintering temperature is important in controlling the intrinsic defects in $\mathrm{ZnO}$ and also the properties of the samples [27].

By doping zinc oxide with different transition metals (TM), [28-31] or rare earth (RE) metals properties like electrical, Optical, and magnetic can be changed [32-35].This can be achieved by modifying the electronic structure and band gap of $\mathrm{ZnO}[36,37]$ making it appropriate for various applications. Physical properties can be modified by doping $\mathrm{ZnO}$ with metal ions like $\mathrm{Cd}^{2+}, \mathrm{Cu}^{2+}, \mathrm{Ni}^{2+}$, $\mathrm{Cr}^{3+}$ and $\mathrm{Mn}^{2+}$ for reasonable applications. Chromium has been utilized to upgrade the optical, electrical, magnetic and luminescent behaviour of $\mathrm{ZnO}$ [38]. By doping $\mathrm{ZnO}$ with different metals like Ni [17], Sr [20], Ca [39], Mn [40], La [41] etc. into ZnO shows NTCR behaviour which is very much 
suitable for thermistor application. Among different phases of chromium oxide, under normal conditions $\mathrm{Cr}_{2} \mathrm{O}_{3}$ is the most stable phase. Therefore conduction properties of $\mathrm{ZnO}$ can be modified by $\mathrm{Cr}$ doping [7]. As the ionic radius of $\mathrm{Cr}$ is very close to that of $\mathrm{Zn}^{2+}, \mathrm{Cr}^{3+}$ can easily enter into $\mathrm{ZnO}$ crystal lattice [42].

The structural and electrical behaviour of oxides can be correlated by complex impedance spectroscopy (CIS) in a broad range of frequencies and also to study their temperature and frequency dependent phenomena [43]. The ac conduction mechanism in amorphous semiconductors can be described by Correlated Barrier Hopping (CBH), Quantum Mechanical Tunneling (QMT) [44], and Hoping over a Barrier [45-47].

Although there are few reports available for ac conductivity study of $\mathrm{Cr}$ doped $\mathrm{ZnO}$, a detailed investigation is not done. In this communication, we have presented the study on the structural, morphological and NTCR behaviour of $\mathrm{Cr}$ doped $\mathrm{ZnO}$ nanoceramics in details. The impedance studies of $\mathrm{Cr}-\mathrm{ZnO}$ pellets is also carried out for a clear understanding of the suitability of $\mathrm{Cr}$ doped $\mathrm{ZnO}$ nanoceramics for thermistor application.

\section{Experimental details}

HEBM technique is used to synthesize $\mathrm{Cr}$ doped $\mathrm{ZnO}\left(\mathrm{Zn}_{1-\mathrm{x}} \mathrm{Cr}_{\mathrm{x}} \mathrm{O}\right.$ with $\mathrm{x}=0$ - 0.04) nanocrystalline samples. Calculated quantity of $\mathrm{ZnO}$ and $\mathrm{Cr}_{2} \mathrm{O}_{3}$ has been milled for $10 \mathrm{~h}$ in a high energy ball mill (PM400 Retsch) in dry milling conditions having ball to powder weight ratio 10:1 with a speed of $300 \mathrm{rpm}$. Milling parameters like rotation speed, time of milling etc. important role for synthesis of $\mathrm{ZnO}$ nanoparticles [48]. The milling process was stopped for $30 \mathrm{~min}$ after every $1 \mathrm{~h}$ of milling. Because of the kinetic energy of grinding medium heat generated during milling and the milling process is exothermic [49]. The milled sample was calcinated at $900{ }^{\circ} \mathrm{C}$ for $2 \mathrm{~h}$ with a heating rate of $2{ }^{\circ} \mathrm{C} / \mathrm{min}$. Then the calcined powder mixed thoroughly with a small amount of PVA for making pellet. The pelletization was done using a hydraulic press at a pressure of $500 \mathrm{Mpa}$ and sintered at $1000{ }^{\circ} \mathrm{C}$ for $2 \mathrm{~h}$. Silver paste was applied on the surface of the pellets and dried at $700{ }^{\circ} \mathrm{C}$ for 15 minutes, to make conductor. The structure of the ball milled calcined powder was determined by XRD D8 Advance, Bruker and field emission scanning electron microscopy (FESEM, Carl Zeiss NTS Ltd, UK). By using the "FullProf" program rietveld refinement of the XRD patterns was carried out [50] to quantify different structural parameter. The electrical behavior of the samples were studied using Impedance analyzer (Hioki LCR Hi-tester-3532-50) in a frequency range of $100 \mathrm{~Hz}-1 \mathrm{MHz}$ and 
in a temperature range of $300{ }^{\circ} \mathrm{C}$ to $500{ }^{\circ} \mathrm{C}$. The schematic representation of material synthesis experimental process is given in Figure 1.

\section{Results and Discussion}

\subsection{X-ray diffraction}

\subsubsection{Structural parameters analysis}

Figure 2(a) illustrates the XRD pattern of the $10 \mathrm{~h}$ ball milled $\mathrm{Zn}_{1-\mathrm{x}} \mathrm{Cr}_{\mathrm{x}} \mathrm{O}$ samples with different $\mathrm{Cr}$ concentration and Figure 2(b) of $10 \mathrm{~h}$ milled and calcined at $900{ }^{\circ} \mathrm{C}$ samples. All the XRD peaks are matched to wurtzite structure of zinc oxide with a space group $\mathrm{P}_{3} \mathrm{mc}$ and are in good agreement with JCPDS data card 36-1451. It was also found that the peak broadening increases with the concentration of $\mathrm{Cr}$. No supplementary peak associated to $\mathrm{Cr}_{2} \mathrm{O}_{3}$ or impurity was shown in the XRD patterns of synthesized samples (10h milled) up to 3 atomic\% $\mathrm{Cr}$ doping. But in case of $\mathrm{x}=0.04$ only some extra peaks associated to $\mathrm{Cr}_{2} \mathrm{O}_{3}$ were found at $2 \theta=33.71,50.16$ and 54.91 for $\mathrm{x}=0.04$ in case of $10 \mathrm{~h}$ ball milled sample (Figure 2 (a)), which suggests that $\mathrm{Cr}^{3+}$ is replaced by $\mathrm{Zn}^{2+}$ in the $\mathrm{ZnO}$ crystal lattice for $\mathrm{x}=0.01-0.03$ after milling the mixture for $10 \mathrm{~h}$ but for $\mathrm{x}=0.04$ precipitation of $\mathrm{Cr}_{2} \mathrm{O}_{3}$ was observed. The XRD pattern of calcined sample $\left(900{ }^{\circ} \mathrm{C}, 2 \mathrm{~h}\right.$ ) (Figure 2(b)) confirms that the samples up to 4 atomic \% ( $\mathrm{x}=0.04)$ of $\mathrm{Cr}$ retains their structure intact. It indicates when the sample is calcined at the diffused particle when calcined at $900{ }^{\circ} \mathrm{C}$ the substituted $\mathrm{Cr}^{3+}$ ion in the $\mathrm{Zn}^{2+}$ ion positions in $\mathrm{ZnO}$ lattice up to $\mathrm{x}=0.04$ which shows the single phase $\mathrm{Zn}_{1-\mathrm{x}} \mathrm{Cr}_{\mathrm{x}} \mathrm{O}$ material and no precipitation of $\mathrm{Cr}_{2} \mathrm{O}_{3}$ was observed. Thus there is no impurity within range of XRD. Therefore, we believe that upto $4 \%$ of $\mathrm{Cr}(\mathrm{x}=0.04)$ doping is lower than the solubility limit of $\mathrm{Cr}$ ion in $\mathrm{ZnO}$ lattice by high energy ball milling. More than $4 \%$ of $\mathrm{Cr}$ doping in $\mathrm{ZnO}$ was reported by sol gel method and by a number of researchers[51-53]. K. Sebayang et al. reported more than 3.5\% of Cr doping by solid state reaction [54]. It is also noticed that upon calcination the peak intensity increased and FWHM decreased which indicates the crystallinity of the $\mathrm{Zn}_{1-\mathrm{x}} \mathrm{Cr}_{\mathrm{x}} \mathrm{O}$ sample increased after calcination[55].

The structural parameters are obtaind from the Rietveld refinement of the XRD patterns of 10h ball milled $\mathrm{Zn}_{1-\mathrm{x}} \mathrm{Cr}_{\mathrm{x}} \mathrm{O}$ nanoceramics ((Figure 3(a-f)). It has been observed from Figure 3(a) there is no significant modification in the value of lattice parameter (a and c) due to $\mathrm{Cr}$ doping. But a closer study indicates slight increase in the value of both a and $\mathrm{c}$ after $\mathrm{Cr}$ doping which can be due to the lattice distortion cause due to doping. But it decreases with increases in $\mathrm{Cr}$ concentration. This result is consistent with the reported observation [52,53,56,57]. The c/a ratio of $\mathrm{ZnO}$ is not much changed by Cr doping while the volume of unit cell reduces slowly with increase in Cr concentration (Figure 3(b)). The value of $\mathrm{c} / \mathrm{a}=1.60$ shows that the hexagonal structure of pure $\mathrm{ZnO}$ is not distressed due to $\mathrm{Cr}$ doping. The crystallite size and strain was determined by using Scherer equation and W-H method. 
The variation of crystallite size and strain with increase in $\mathrm{Cr}$ concentration were illustrated in Figure 3(c). It was observed that the crystallite size reduces with increases in $\mathrm{Cr}$ concentration in $\mathrm{ZnO}$. This variation of crystallite size is as a result of the substitution of $\mathrm{Cr}$ ion in $\mathrm{ZnO}$ lattice [52].

The reduction in size may be due to lattice distortion of the $\mathrm{ZnO}$ crystal structure due to incorporation of smaller size $\mathrm{Cr}$ atom into $\mathrm{ZnO}$ lattice [58]. Similar result is also reported by a number of researchers [57,59-61] The lattice strain was increased after $\mathrm{Cr}$ doping but by increasing the $\mathrm{Cr}$ concentration it was found to be decreased. The result is quite similar as observed by Santi Septiani et al.[56]. Figure 3(d) shows the variation of specific surface area and u-parameter with $\mathrm{Cr}$ concentration. The specific surface area (S) was computed by the relation

$\mathrm{S}=\frac{6 \times 10^{3}}{\mathrm{Dp} . \rho}$

Where $\mathrm{S}=$ specific surface area, $\mathrm{Dp}=$ size of the particle $(\mathrm{nm}), \rho=$ density of $\mathrm{ZnO}\left(5.606 \mathrm{gm} / \mathrm{cm}^{3}\right)$.

The specific surface area of $\mathrm{Cr}$ doped $\mathrm{ZnO}$ shows larger value upto $2 \%$ of $\mathrm{Cr}$ doping than pure $\mathrm{ZnO}$ which is slightly decreases for 3 and $4 \%$ of doping. This large value of S shows that sample is more reactive [62].

The $\mathrm{u}$ parameter was calculated by using the formula

$\mathrm{u}=\frac{1}{3}\left(\frac{a^{2}}{c^{2}}\right)+\frac{1}{4}$

Slight increase in the value of u-parameter also observed (Figure 3(d)). The change in Zn-O bond length due to doping is calculated using relation

$$
L=\sqrt{\frac{a^{3}}{3}+\left(\frac{1}{2}-u\right)^{2} c^{2}}
$$

Where a and $\mathrm{c}$ are lattice parameter and $\mathrm{u}$ is the oxygen positional parameter. The effect $\mathrm{Cr}$ doping on the variation of bond length $\mathrm{Zn}-\mathrm{O}$ is shown in Figure 3(e). A very small variation of bond length with increase in Cr doping was observed which confirms replacement of ion [63]. Because of the variation in bond length lattice deformation takes place. The lattice distortion degree was calculated by the relation 4 .

$R=\frac{2 a\left(\frac{2}{3}\right)^{\frac{1}{2}}}{c}$ 
In our case, the lattice parameter (a and c) and $\mathrm{Zn}-\mathrm{O}$ bond length was found to be decreased with increasing the $\mathrm{Cr}$ concentration, which confirms the reduction of crystallite size also the unit cell volume and applicable modification in micro strain .

The average value of $\delta$ was calculated by using the relation

$\delta=\frac{15 \beta \cos \theta}{4 \text { a D }}$

By taking first three major planes (100), (002) and (101) are shown in Figure 3(f). It was found that the value of dislocation density $(\delta)$ for $\mathrm{x}=0.01$ doped $\mathrm{ZnO}$ is lower than pure $\mathrm{ZnO}$ which increases with rise in $\mathrm{Cr}$ concentration. The highest value of dislocation density was observed for $\mathrm{x}=0.04$, indicates the highest hardness among all the samples [64].

\subsection{Morphological study by FESEM}

The surface morphology of all samples was studied by FESEM. Figure 4(i) illustrates the FESEM pattern of $10 \mathrm{~h}$ milled undoped and $\mathrm{Cr}$ doped $\mathrm{ZnO}$ nanoceramics. All compositions exhibit spherical shape with diverse particle sizes. From these pictures it is seen that the particle size reduces with increase of $\mathrm{Cr}$ concentration from $\mathrm{x}=0$ to 0.03 but for $\mathrm{x}=0.04$, there is a start of agglomeration of the particles forming bigger particles. The elemental composition of all synthesized sample are obtained from EDX and are shown in Figure 4(ii). From Figure ((ii) (a)) it is obvious that the sample contains only $\mathrm{Zn} \& \mathrm{O}$ where as other sample consists of $\mathrm{Zn}, \mathrm{Cr}$ and $\mathrm{O}$. Presence of any other impurity was not found in the sample, which indicates the purity of the synthesized sample, again the intensity of $\mathrm{Cr}$ increases with increasing $\mathrm{Cr}$ incorporation in $\mathrm{ZnO}$ lattice. So this measurement confirms the presence of $\mathrm{Cr}$ in the $\mathrm{Cr}$ doped $\mathrm{ZnO}$ samples.

\subsection{Impedance $\left(Z^{*}\right)$ Analysis}

The electrical behaviour of all the synthesized material was carried out by Complex Impedance spectroscopy (CIS) in the frequency range $100 \mathrm{~Hz}-1 \mathrm{MHz}$. The output response of such measurement in a complex plot shows in the pattern of a sequence of semicircles, which helps to split the contribution of grain boundary and bulk. The complex impedance of a system can be described as [65]:

$$
Z^{*}=Z^{\prime}+\mathrm{j} Z^{\prime \prime}
$$

where $Z^{\prime}=Z \cos \theta$ and $Z^{\prime \prime}=Z \sin \theta$. 
Similarly Figure 5(x =0 - 0.04) illustrates the variation of real part of impedance $\left(Z^{\prime \prime}\right)$ with frequency at temperature range of $300-500{ }^{\circ} \mathrm{C}$ for $\mathrm{Zn}_{1-\mathrm{x}} \mathrm{Cr}_{\mathrm{x}} \mathrm{O}$ nanoceramics sintered at $1000{ }^{\circ} \mathrm{C}$ with different concentration of $\mathrm{x}$. From the figure it was found that the magnitude of $\mathrm{Z}^{\prime}$ (i.e resistance) reduces with rise in temperature and frequency for all samples which indicate the chances of increase in ac conductivity with temperature and frequency [66]. Figure 5(f) shows the variation of $\mathrm{Z}^{\prime}$ with the $\mathrm{Cr}$ concentration at a particular temperature and frequency $\left(300^{\circ} \mathrm{C}\right.$ and $\left.20 \mathrm{kHz}\right)$. It was observed that with $\mathrm{Cr}$ doping the impedance $\left(\mathrm{Z}^{\prime}\right)$ becomes higher which increases linearly with raise in Cr concentration.

The increase of $\mathrm{Z}^{\prime}$ with increasing $\mathrm{Cr}$ concentration in $\mathrm{ZnO}$ at $300{ }^{\circ} \mathrm{C}$ for all $\mathrm{Cr}$ doped samples shows a decrease in the value of ac conductivity with increase in concentration. The decrease in degree of $Z^{\prime}$ on raise in temperature shows their NTCR behavior in the studied temperature and frequency range. Again at low frequency and temperature region the value of $Z^{\prime}$ is high which may be because of the polarization in the samples. Relaxation process in the materials was observed in the low frequency range [67]. In the temperature range of $300-500{ }^{\circ} \mathrm{C} \mathrm{Zn}_{1-\mathrm{x}} \mathrm{Cr}_{\mathrm{x}} \mathrm{O}$ nanoceramics shows NTCR behaviour which suggests that, the material can be a suitable candidate for NTCR thermistor applications. The variation of imaginary part of impedance ( $\left.Z^{\prime \prime}\right)$ with frequency at different temperature for $\mathrm{Zn}_{1-\mathrm{x}} \mathrm{Cr}_{\mathrm{x}} \mathrm{O}$ samples with different concentration of $\mathrm{Cr}$ was shown in Figure 6. The effect of doping is observed from the variation in the magnitude of $Z "$ ", peak expansion and asymmetry. At higher temperature each curve exhibit peak. A single peak $\left(Z^{\prime \prime}{ }_{\max }\right)$ which is temperature dependent is seen for all the samples. The peak shifts towards higher frequencies as the temperature is increased and a broadening observed with the decrease in peak height. This broadening suggest the temperature dependent relaxation phenomena in the material [68]. The relaxation phenomena in the material may be due to the presence of immobile species at low temperature and defect at high temperature[55]. The variation of the peak position and height with concentration of Cr doping was shown in Figure 6(f). The Cr shifts peak frequency to the higher value and it increases linearly with increase in Cr concentration up to $\mathrm{x}=0.04$.

Figure 7 shows the cole - cole plot of $\mathrm{Zn}_{1-\mathrm{x}} \mathrm{Cr}_{\mathrm{x}} \mathrm{O}$ nanoceramics. The observed semicircular arc have their centers laying off the real axis indicating a non-Debye type of relaxation with distribution of relaxation time. The semicircular arcs gradually decrease with increasing temperature. The effect of temperature on impedance characteristics of the material becomes clearly visible in the figure. It clearly shows that the material is temperature and frequency dependant. This non ideal behavior can be related to the factors like grain boundaries, grain orientation, stress-strain phenomena and defect distribution [50]. 
The semicircular pattern in the impedance spectrum is representative of the electrical processes taking place in the nanoceramic samples. The equivalent electrical circuit of $\mathrm{Zn}_{1-\mathrm{x}} \mathrm{Cr}_{\mathrm{x}} \mathrm{O}$ nanoceramics was carried out with ZVIEW software by fitting the experimental impedance data. It was found that the circuit model of $\mathrm{ZnO}$ and $\mathrm{Zn}_{1-\mathrm{x}} \mathrm{Cr}_{\mathrm{x}} \mathrm{O}$ nanoceramics sample is a parallel combination of bulk resistance $\left(\mathrm{R}_{\mathrm{b}}\right)$ and bulk capacitance $\left(\mathrm{C}_{\mathrm{b}}\right)$ and the circuit diagram was as shown in Figure 8. The value of bulk resistance $\left(R_{b}\right)$ and bulk capacitance $\left(C_{b}\right)$ obtained at temperature $300-500^{\circ} \mathrm{C}$ was shown in Table 1 and 2 for $\mathrm{ZnO}$ and $\mathrm{Cr}$ doped samples respectively.

The impedance loss spectra has been used to evaluate the relaxation time $(\tau)$ of the electrical phenomena taking place in the material at a different temperature. The relaxation time $(\tau)$ calculated from the plot of $Z^{\prime \prime}$ versus $\log$ (f) by using the relation $\tau=\frac{1}{\omega}=\frac{1}{2 \pi f_{\max }}$ [62], where $\mathrm{f}_{\max }$ is the frequency at which $Z^{\prime \prime}$ was found to be maximum. The value of $\tau$ was found to be decreasing with the rise in temperature. The relaxation time is independent of the sample geometries but dependent on the microstructure and intrinsic properties of the material. Figure 9 represents the typical variation of relaxation time $(\tau)$ with the inverse of temperature for $\mathrm{Zn}_{1-\mathrm{x}} \mathrm{Cr}_{\mathrm{x}} \mathrm{O}$ in the temperature range of $300-400{ }^{\circ} \mathrm{C}$. From the figure it was observed that $\mathrm{ZnO}(\mathrm{x}=0)$ shows less relaxation time than $\mathrm{Cr}$ doped sample and it increases with increase in $\mathrm{Cr}$ concentration. Among the doped samples $\mathrm{x}=0.01$ shows less relaxation time which has a faster response for small stimuli than others. The $\tau$ value of $\mathrm{Cr}$ doped $\mathrm{ZnO}$ sample was found to be decreased with increase in temperature which is a typical semiconductor type behavior.

Again the nature of variation of $\tau$ with temperature for all samples appear to follow the Arrhenius relation $\tau=\tau_{0} \exp \left[-\mathrm{E}_{\mathrm{a}} / \mathrm{KT}\right]$ [69]. Where $\tau_{0}$ pre exponential factor, $\mathrm{E}_{\mathrm{a}}=$ activation energy, $\mathrm{K}=$ Boltzmann constant and $\mathrm{T}=$ absolute temperature. The activation energy was evaluated from the graph of $\log \tau$ Vs 1000/T shown in Figure 10. In Cr doped sample, the activation energy $\mathrm{E}_{\mathrm{a}}$ of $\mathrm{ZnO}$ decreases with doping and the $\mathrm{E}_{\mathrm{a}}$ value was found to be less than $1 \mathrm{eV}$.

\section{Conclusions}

$\mathrm{Cr}$ doped $\mathrm{ZnO}\left(\mathrm{Zn}_{1-\mathrm{x}} \mathrm{Cr}_{\mathrm{x}} \mathrm{O}, \mathrm{x}=0,0.01,0.02,0.03\right.$ and 0.04$)$ was successfully synthesized by high energy ball milling technique. Diffusion of $\mathrm{Cr}$ into $\mathrm{ZnO}$ lattice by displacing $\mathrm{Zn}$ up to $3 \%$ ( $\mathrm{x}=0.03$ ) was observed after $10 \mathrm{~h}$ of milling. But after calcination at $900{ }^{\circ} \mathrm{C} 4 \% \mathrm{Cr}(\mathrm{x}=0.04)$ can be soluble in $\mathrm{ZnO}$. So the solubility $\mathrm{Cr}$ in $\mathrm{ZnO}$ can be extended after calcination. The structural, morphological and electrical properties of the materials are studied in detail. Particle size increases after $\mathrm{Cr}$ doping as obtained from XRD and FESEM result. $\mathrm{Zn}_{1-\mathrm{x}} \mathrm{Cr}_{\mathrm{x}} \mathrm{O}$ ceramics have a novel NTCR effect within 
temperature range $300-500{ }^{\circ} \mathrm{C}$. The impedance spectroscopy data shows a single semicircle in the high frequency region corresponding to the bulk properties of the ceramic sample. The impedance pattern suggests a decrease in bulk resistance with increase in temperature. Distributed relaxation time suggests that the relaxation in the synthesized sample is of non-Debye type and the relaxation time decreases with increase in temperature. Our observation was found to be suitable for high temperature sensor applications. 


\section{Figure:}

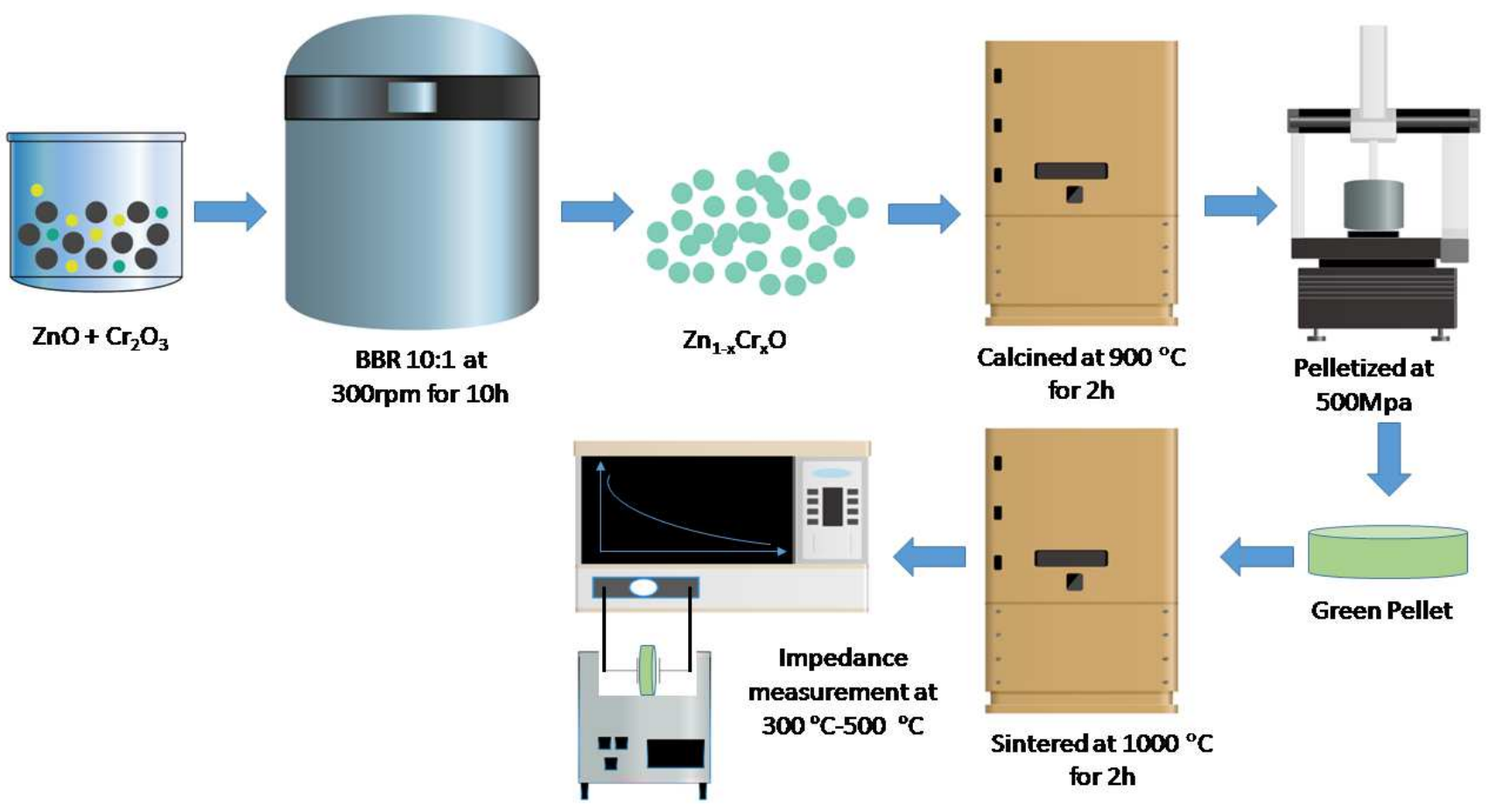

Figure 1: Schematic representation of methodology 

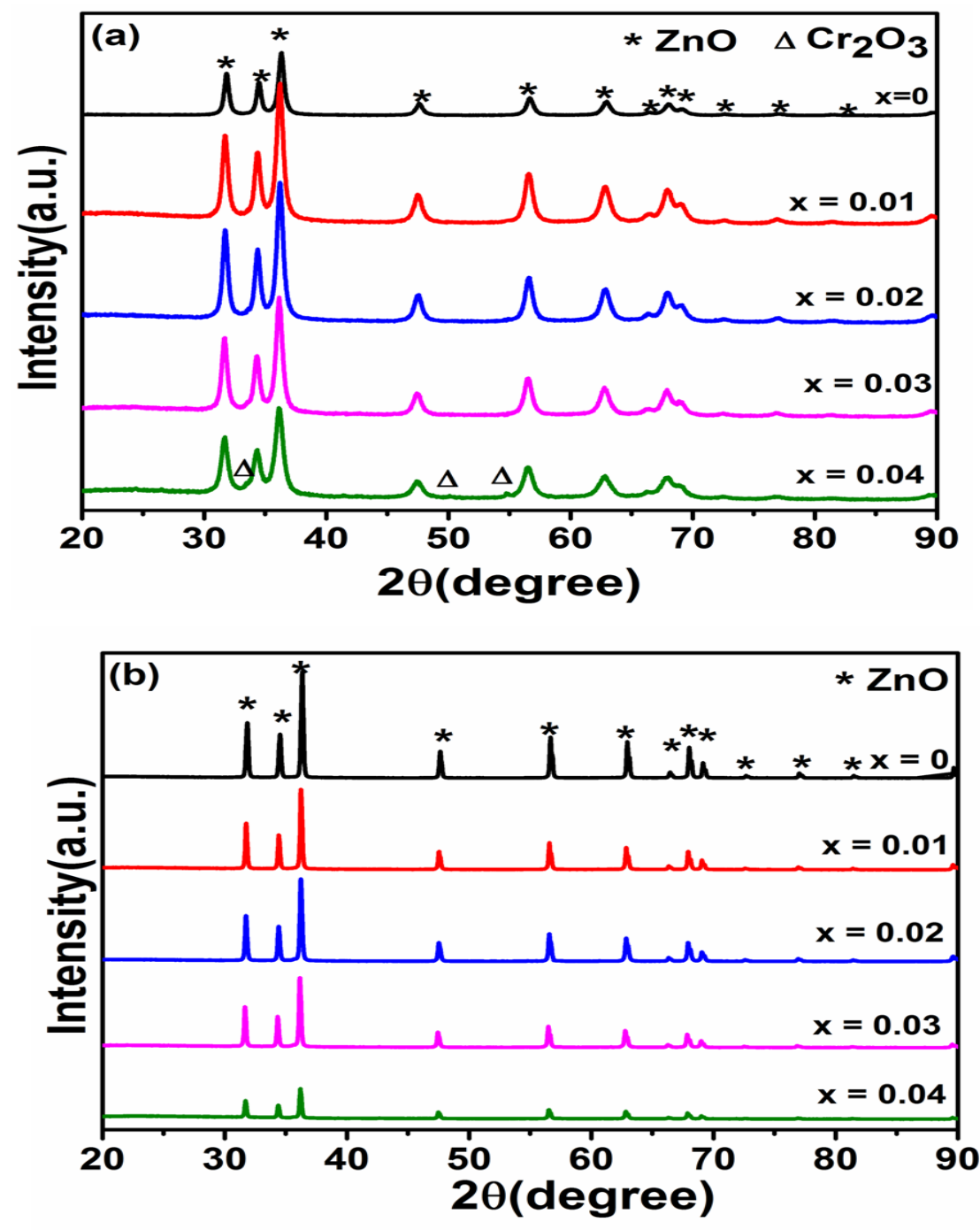

Figure 2: XRD pattern of $\mathrm{Zn}_{1-\mathrm{x}} \mathrm{Cr}_{\mathrm{x}} \mathrm{O}(\mathrm{x}=0,0.01,0.02,0.03$, and 0.04$)$ nanoceramics (a) after ball milling for $10 \mathrm{~h}$ and (b) after ball milling for $10 \mathrm{~h}$ followed by calcination at $900{ }^{\circ} \mathrm{C}$ for $2 \mathrm{~h}$. 

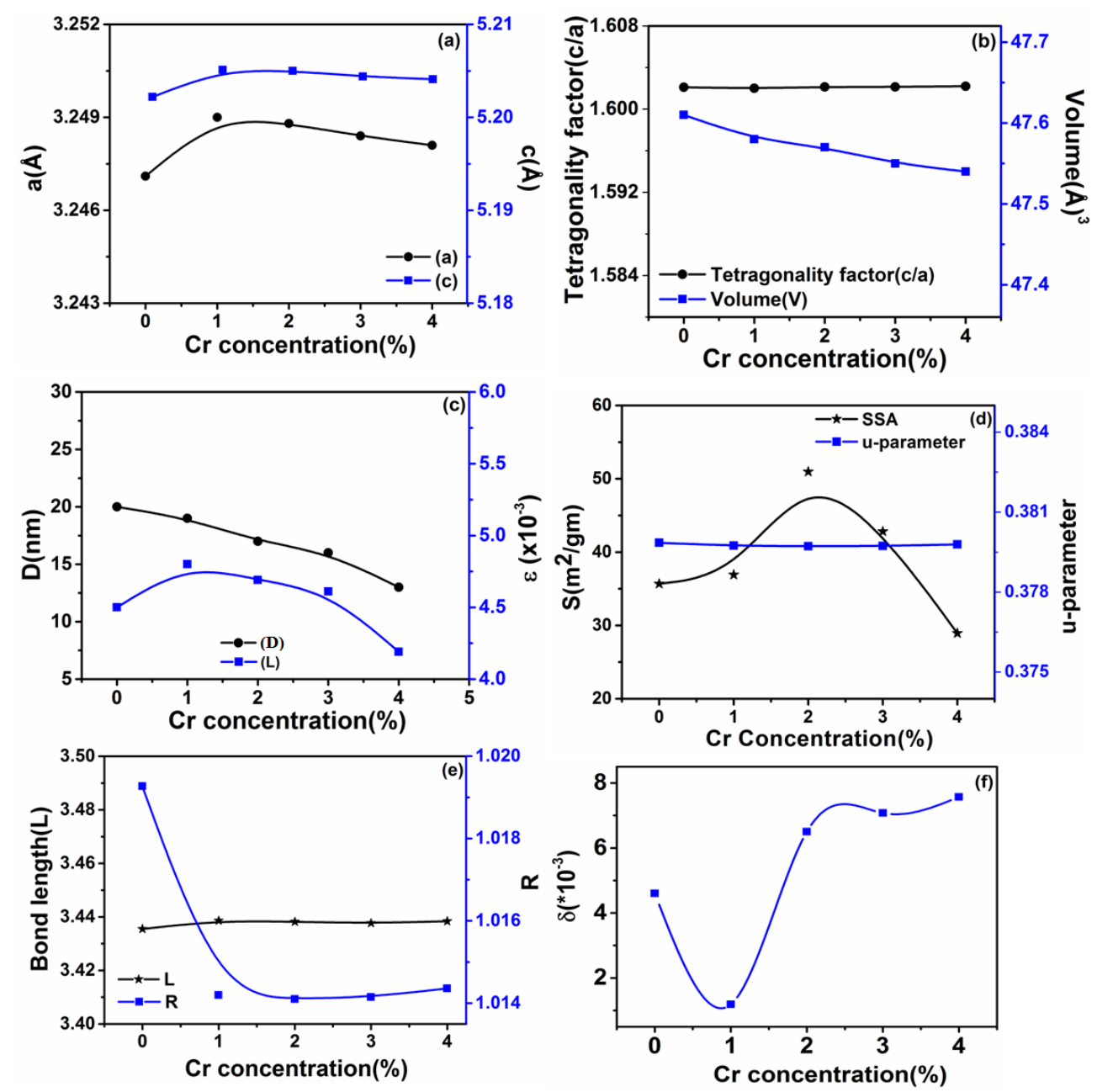

Figure 3: Variation of structural parameter with $\mathrm{Cr}$ concentration of $10 \mathrm{~h}$ ball milled $\mathrm{Zn}_{1-\mathrm{x}} \mathrm{Cr}_{\mathrm{x}} \mathrm{O}$ $(\mathrm{x}=0,0.01,0.02,0.03$ and 0.04$)$ nanoceramics (a) Latice pameter ' $\mathrm{a}$ ' and 'c',(b) c/a ratio and volume (V), (c) crystallite size (D) and strain ( $(\varepsilon)$, (d) specific surface area (S) and u-parameter (e) bond length $(\mathrm{L})$ and crystal lattice distortion degree (R) and (f) dislocation density $(\delta)$. 

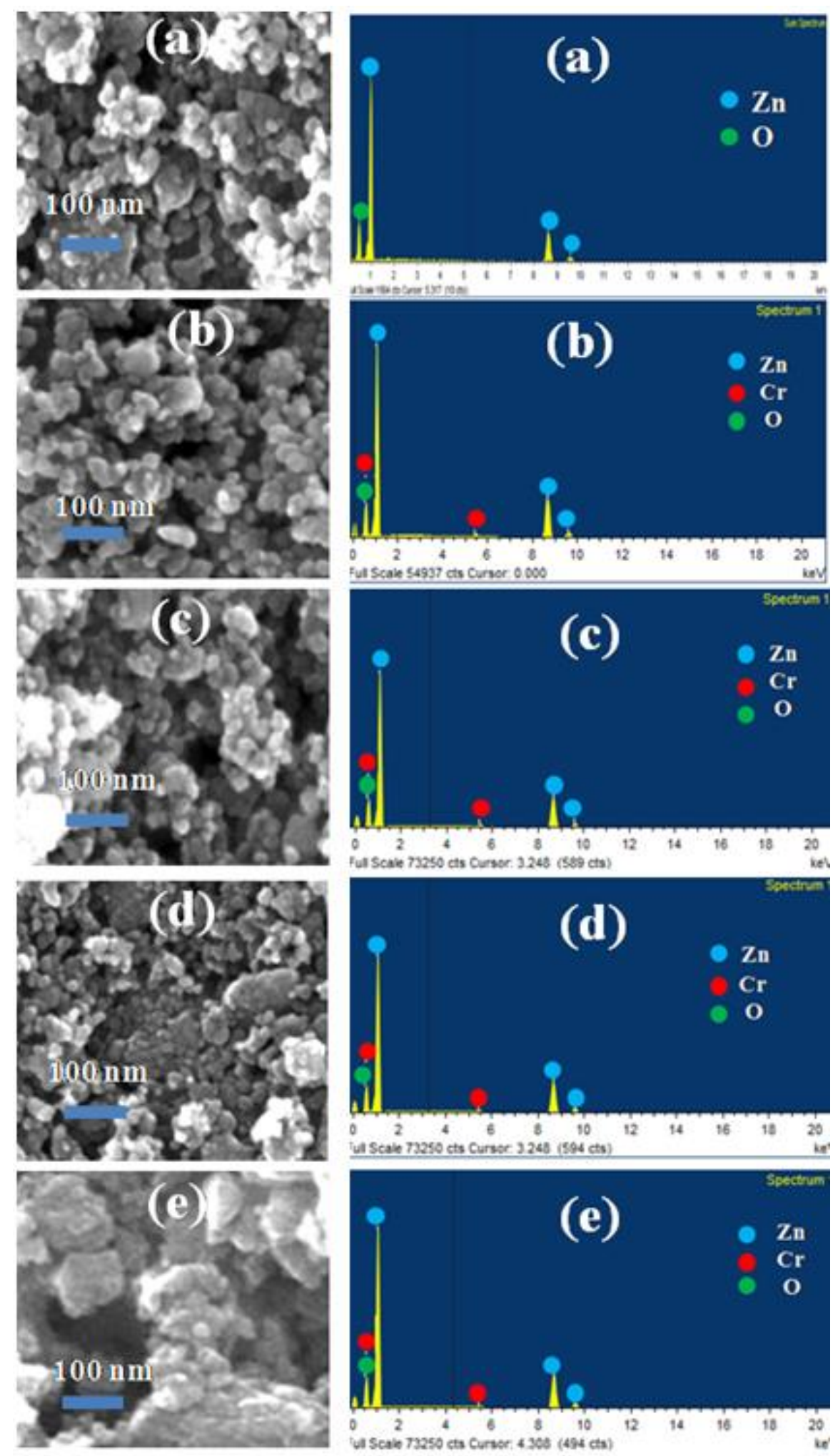

(i)

(ii)

Figure 4: The FESEM micrograph of $\mathrm{Zn}_{1-\mathrm{x}} \mathrm{Cr}_{\mathrm{x}} \mathrm{O}$ (a) $\mathrm{x}=0$, (b) $\mathrm{x}=0.01$, (c) $\mathrm{x}=0.02$, (d) $\mathrm{x}=0.03$ and (e) $\mathrm{x}=0.04$ samples (i) $10 \mathrm{~h}$ milled uncalcined powder, and (ii) EDX of $10 \mathrm{~h}$ milled $\mathrm{Zn}_{1-\mathrm{x}} \mathrm{Cr}_{\mathrm{x}} \mathrm{O}$ samples. 

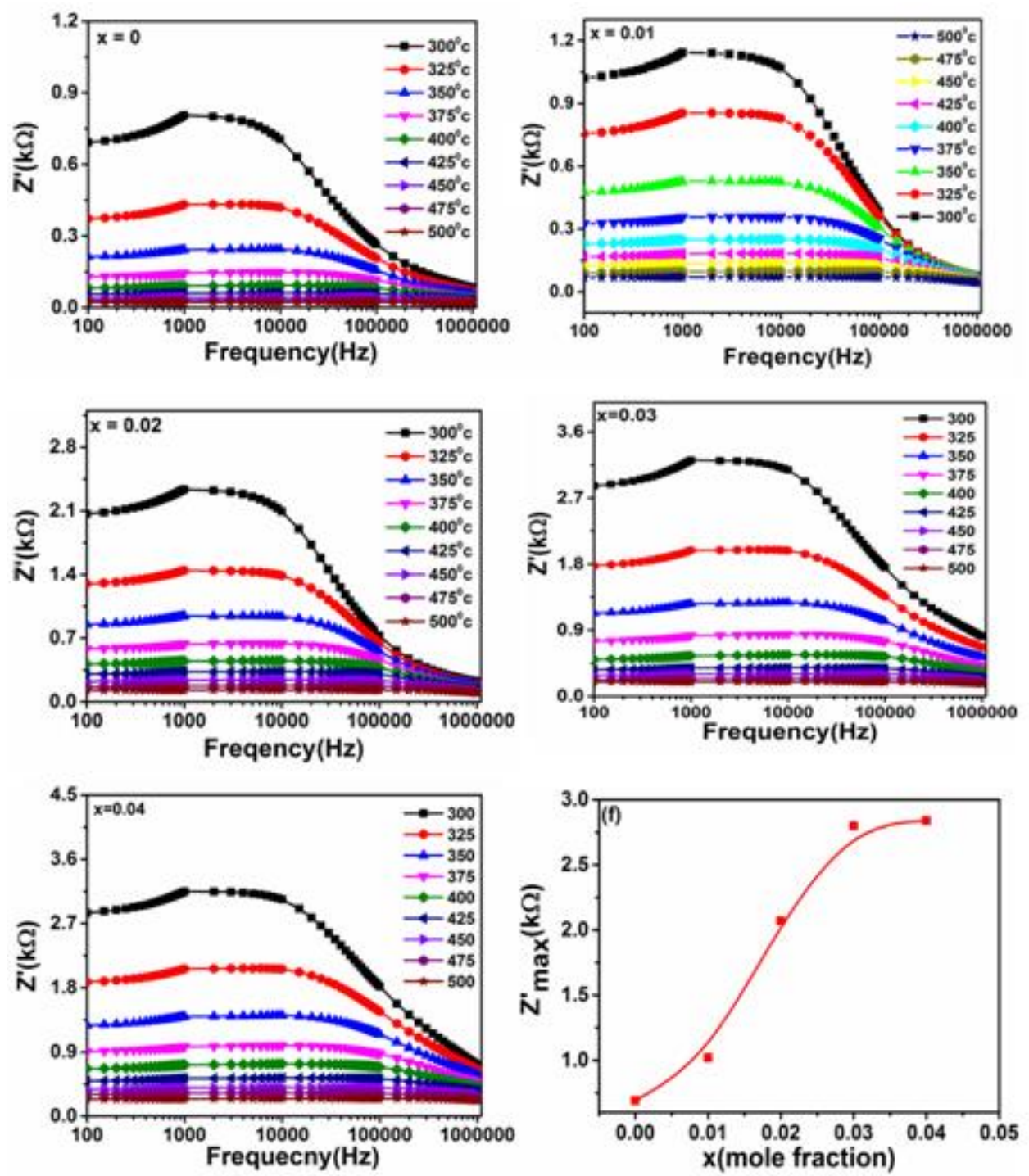

Figure 5: Variation of frequency with $Z^{\prime}$ of the pellet sample prepared by the $10 \mathrm{~h}$ milled powder calcinated at $900{ }^{\circ} \mathrm{C}$ for $2 \mathrm{~h}$ and sintered at $1000{ }^{\circ} \mathrm{C}$ for $2 \mathrm{~h}$ of $\mathrm{Zn}_{1-\mathrm{x}} \mathrm{Cr}_{\mathrm{x}} \mathrm{O}(\mathrm{x}=0-0.04)$ nanoceramics and (f) with different $\mathrm{Cr}$ concentration at a particular temperature $\left(300^{\circ} \mathrm{C}\right)$ and frequency $20 \mathrm{kHz}$. 

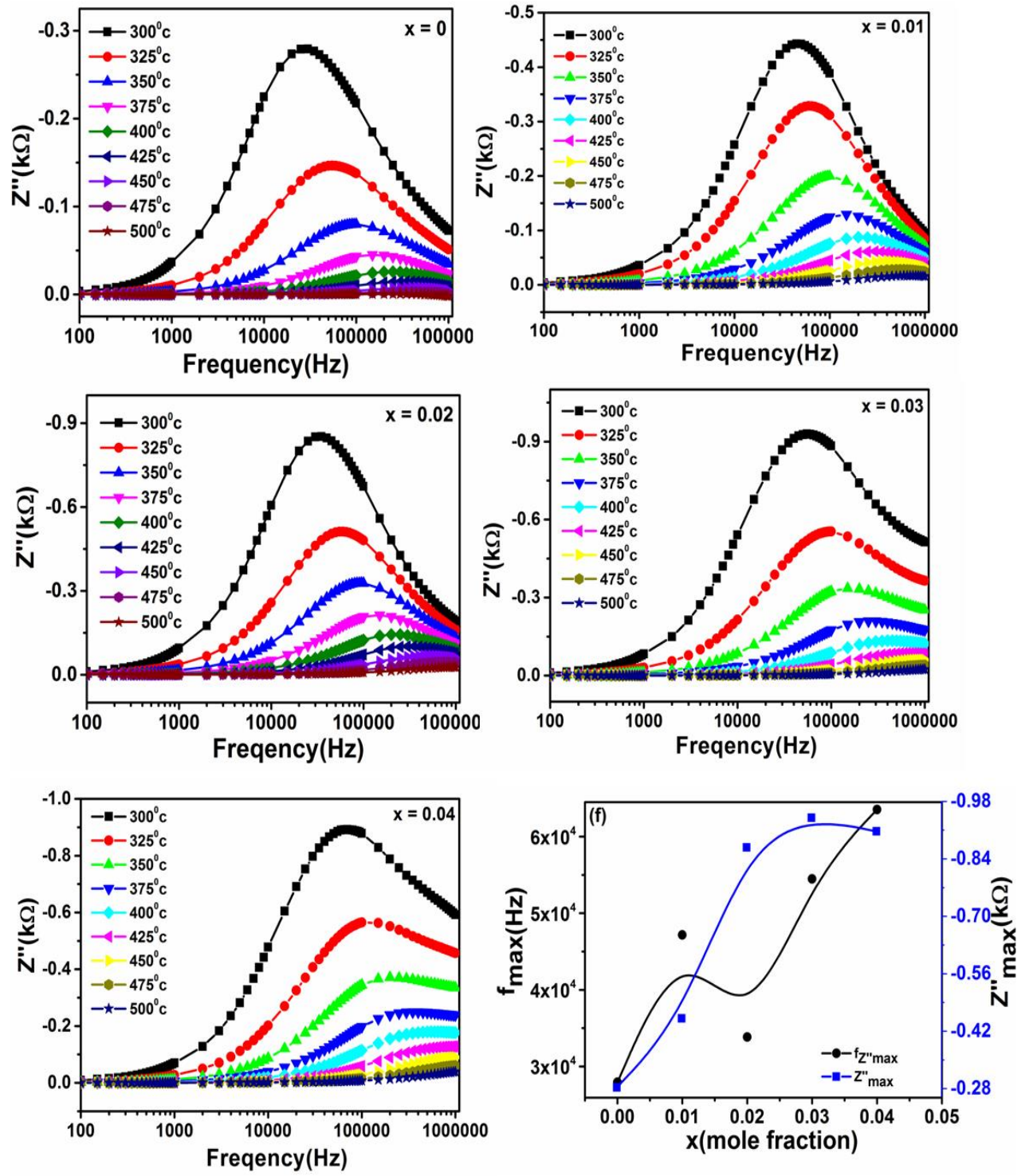

Figure 6: Variation of $\mathrm{Z}^{\prime \prime}$ with frequency of $\mathrm{Zn}_{1-\mathrm{x}} \mathrm{Cr}_{\mathrm{x}} \mathrm{O}(\mathrm{x}=0$ - 0.04) of the pellet sample prepared from the $10 \mathrm{~h}$ milled powder calcinated at $900{ }^{\circ} \mathrm{C}$ for $2 \mathrm{~h}$ with sintering at $1000{ }^{\circ} \mathrm{C}$ for $2 \mathrm{~h}$ and (f) Variation of $\mathrm{f}_{\max }$ and $\mathrm{Z}^{\prime \prime}{ }_{\max }$ with different $\mathrm{Cr}$ concentration at a particular temperature $\left(300^{\circ} \mathrm{C}\right)$ and frequency $20 \mathrm{kHz}$. 

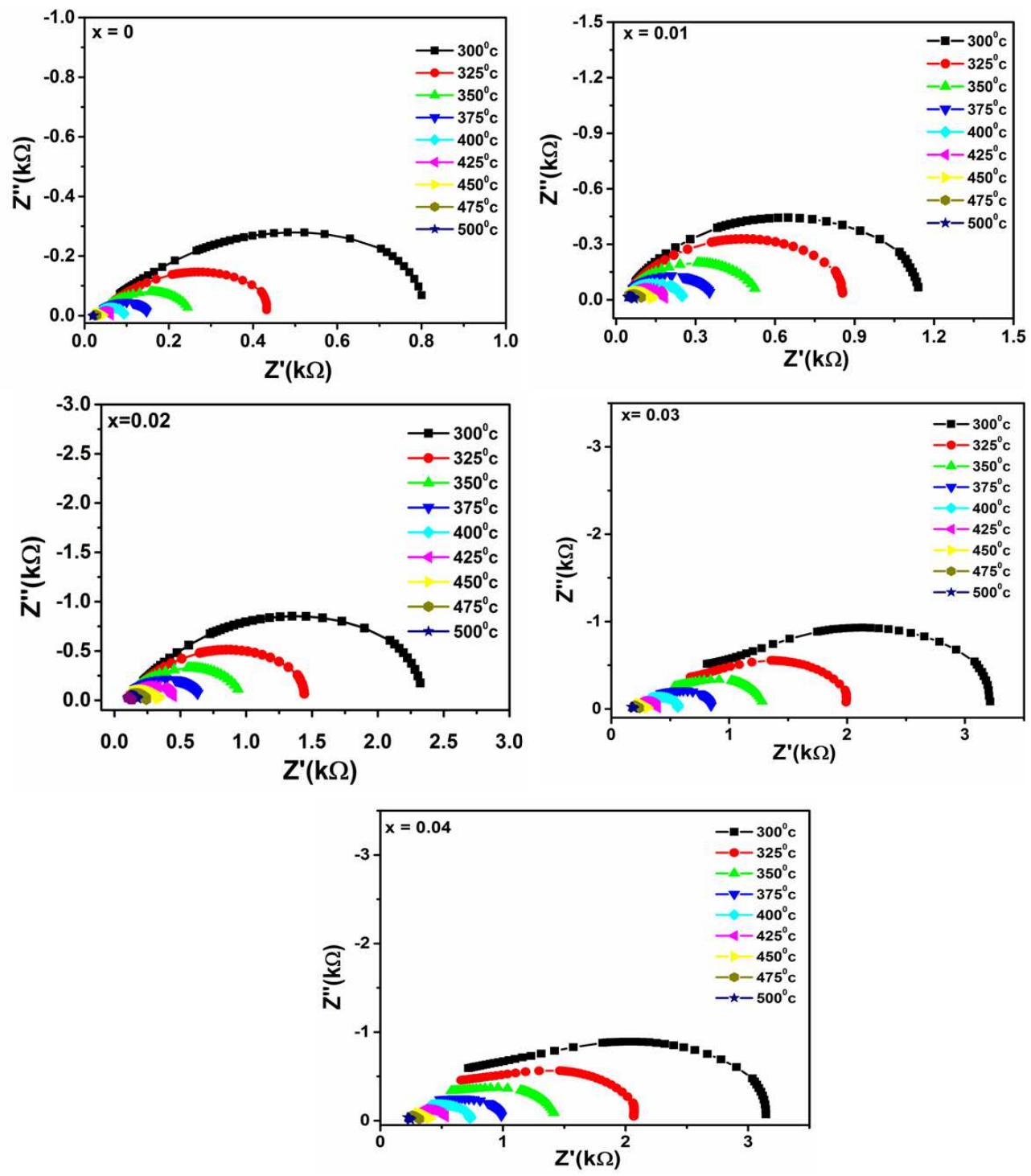

Figure 7: $\mathrm{Z}^{\prime}$ vs $\mathrm{Z}^{\prime \prime}$ plot of $\mathrm{Zn}_{1-\mathrm{x}} \mathrm{Cr}_{\mathrm{x}} \mathrm{O}(\mathrm{x}=0$ - 0.04) nanoceramics.

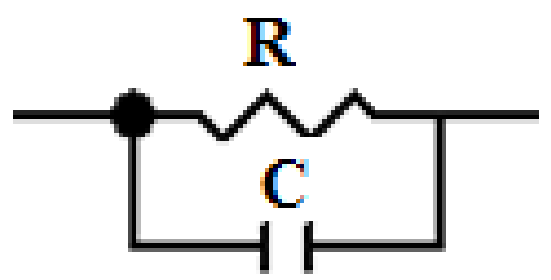

Figure 8: Corresponding circuit diagram of $\mathrm{Cr}$ doped $\mathrm{ZnO}$ nanoceramics. 


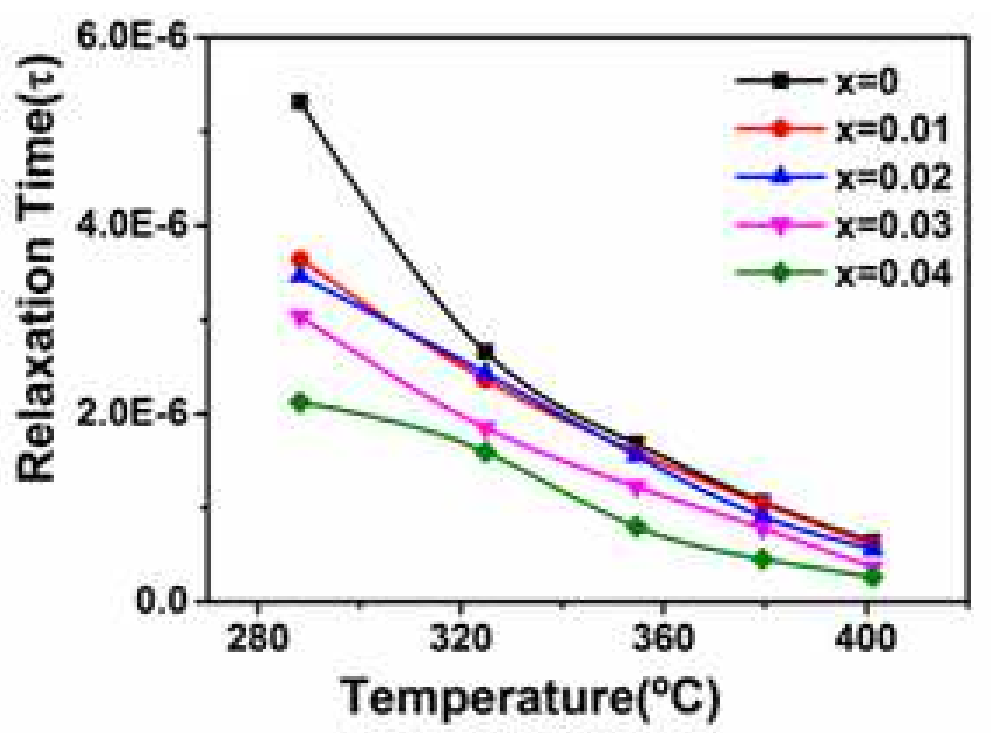

Figure 9: Variation of relaxation time $(\tau)$ with inverse of temperature of $\mathrm{Zn}_{1-\mathrm{x}} \mathrm{Cr}_{\mathrm{x}}(\mathrm{x}=0,0.01,0.02,0.03$ and 0.04 ) of the pellet samples prepared using the $10 \mathrm{~h}$ milled powders calcinated at $900{ }^{\circ} \mathrm{C}$ for $2 \mathrm{~h}$ and sintered at $1000^{\circ} \mathrm{C}$ for $2 \mathrm{~h}$. 

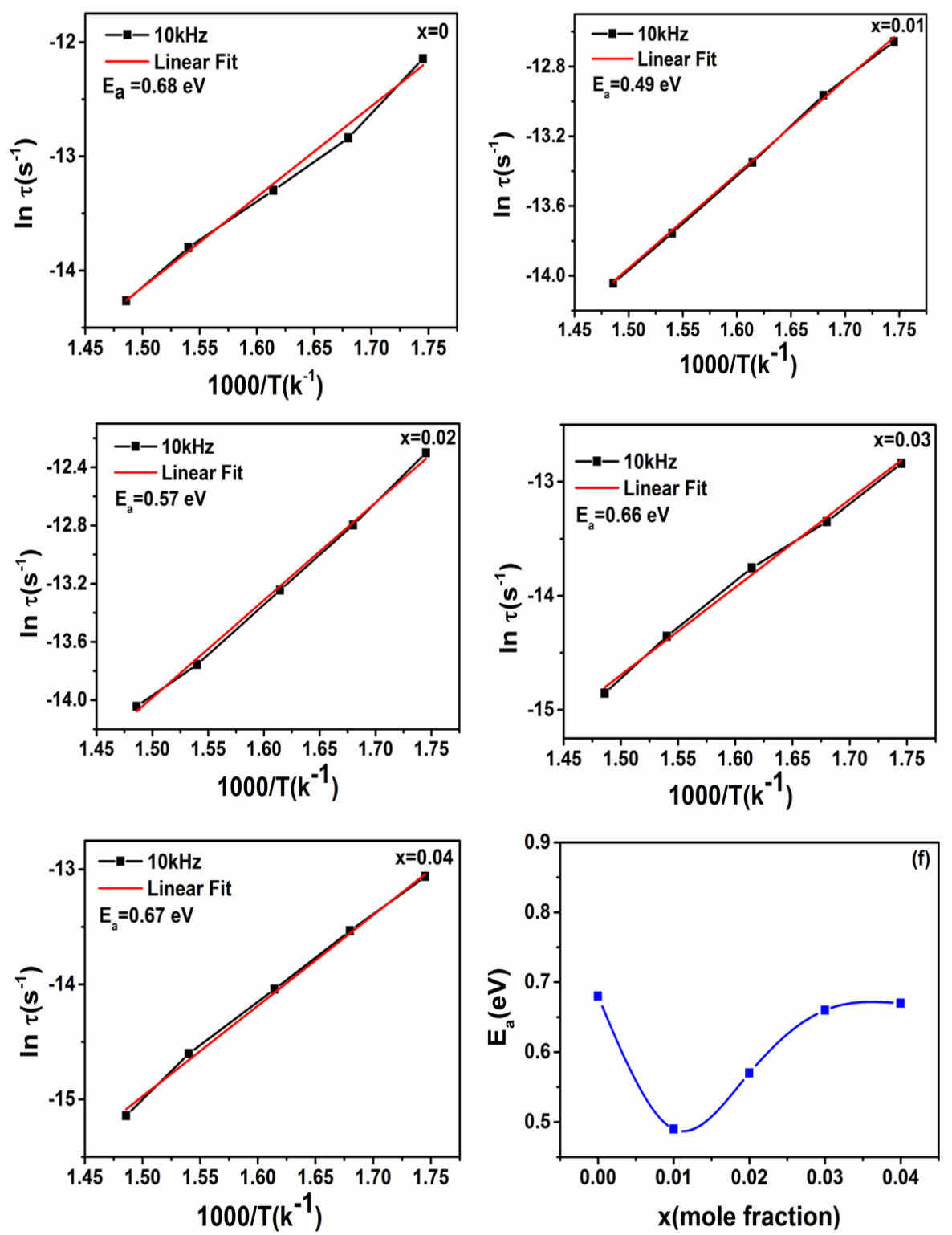

Figure 10: Variation of relaxation time $(\tau)$ with $10^{3} / \mathrm{T}$ of $\mathrm{Zn}_{1-\mathrm{x}} \mathrm{Cr}_{\mathrm{x}} \mathrm{O}(\mathrm{x}=0-0.04)$ nanoceramics (for impedance data) and (f) variation of $\mathrm{E}_{\mathrm{a}}$ with $\mathrm{Cr}$ concentration. 
Table 1: Bulk resistance $\left(\mathrm{R}_{\mathrm{b}}\right)$ and bulk capacitance $\left(\mathrm{C}_{\mathrm{b}}\right)$ of $\mathrm{Zn}_{1-\mathrm{x}} \mathrm{Cr}_{\mathrm{x}} \mathrm{O}(\mathrm{x}=0-0.04)$ ceramics calcined at $900{ }^{\circ} \mathrm{C}$ followed by sintered at $1000{ }^{\circ} \mathrm{C}$.

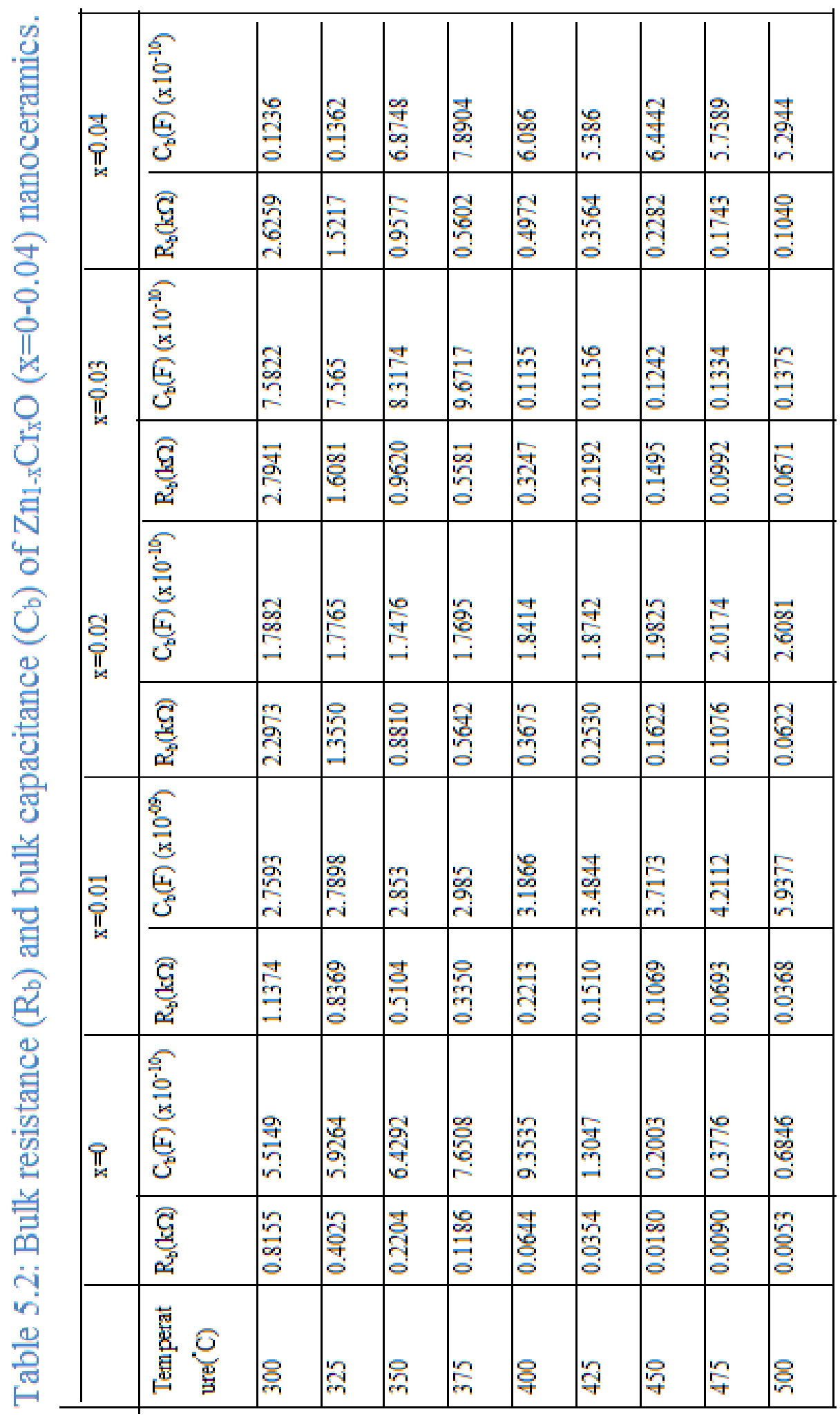




\section{Acknowledgment}

The authors would like to thank the Science and Engineering Research Board (SERB), Govt. of India for providing financial support to carry out the research work of this paper for the project CRG/2019/003315.

\section{References:}

1. R. Jadhav, D. Kulkarni,V. Puri, J Mater Sci. Mater Electron. 21,503 (2010).

2. T. Abbas, Y. Khan, M. Ahmad, S. Anwar, Solid. State. Commun. 82, 701 (1992).

3. M. Mehedi Hassan, W. Khan, A. Azam, and A. H. Naqvi, J. Ind. Eng. Chem. 21, 283 (2015).

4. A. Ghosh, N. Kumari, and A. Bhattacharjee, J. Nanosci. Nano Technol 2, 485 (2014).

5. H. M. Galindo, Y. Carvajal, E. Njagi, R. A. Ristau, and S. L. Suib, Am. Chem. Soci. J. 26, 13677 (2010).

6. M. Mittal, M. Sharma, and O. P. Pandey, Sol. Energy 110, 386 (2014).

7. R.O. Yathisha, Y. Arthoba Nayaka, C.C. Vidyasagar, Mater. Chem. Phy 181, 167 (2016).

8. A. Franco Jr, H.V.S. Pessoni, Physica B 506, 145 (2017).

9. S. Goela, N. Sinhab, H. Yadava, A.bhilash J. Josepha, B.nay Kumara, Physica E 91, 72 (2017).

10. J. H. Jun, H. Seong, K. Cho, B. M. Moon, and S. Kim, Ceram. Int. 35, 2797 (2009).

11. M. Suchea, S. Christoulakis, K. Moschovis, N. Katsarakis, and G. Kiriakidis, Thin Solid Films 515, 551 (2006).

12. N. Sekine, C. H. Chou, W. L. Kwan, and Y. Yang, Org. Electron. Physics, Mater. Appl. 10, 1473 (2009).

13. S.J. Pearton, D.P. Norton, Y.W. Heo, L.C. Tien, M.P. Ivill, Y. Li, B.S. Kang, F. Ren,J. Kelly, A.F. Hebard, J. Electron. Mater.35, 862 (2006).

14. Y. Roig, S. Marre, T. Cardinal, and C. Aymonier, Angew. Chemie - Int. Ed. 50, 12071 (2011).

15. Z. L. Wang and J. Song, Science. 312, 242 (2006).

16. H. Kim, A. Piqué, J. Horwitz, H. Murata, Z. Kafafi, C. Gilmore, and D. Chrisey, Thin Solid Films 798, 377 (2000).

17. X. Sun, H. Zhang, Y. Liu, J. Guo, Z.Cheng, J. Adva.Ceram. 5, 329 (2016),

18. H. Zhang, B. Chen, H. Jiang, C. Wang, H. Wang, and X. Wang, Biomaterials 32, 1906 (2011).

19. Z. Joshi , D. Dhruv, K.N. Rathod, J.H. Markna, A. Satyaprasad, A.D. Joshi, P.S. Solanki, N.A. Shah, J. Mater. Sci. Technol.34, 488 (2018).

20. S.H. Hsieh, J.M. Ting, Appl. Surf. Sci. 427, 465(2018).

21. T. Das, B. K. Das, K. Parashar, R. Kumar, H. K. Choudhary, A. V. Anupama, B. Sahoo, P. K. Sahoo, and S. K. S. Parashar, J. Mater. Sci. Mater. Electron. 28, 13587 (2017). 
22. R. Beura, R. Pachaiappan, P. Thangadurai, Appl. Surf. Sci. 433, 887(2018).

23. S. Choudhury, S. Sain, M.K. Mandal, S.K. Pradhan, A.K. Meikap, Phys. E Low-Dimensional Syst. Nanostructures. 81, 122(2016).

24. L. Tong, W.Li, O. Shen, H. Rong, L. Gong, Materials Letters 218, 1(2018).

25. H.H. Mohamed Journal of Photochemistry and Photobiology A: Chemistry, S1010603017312625 (2017).

26. B. K. Das, T. Das, K. Parashar, A. Thirumurugan, and S. K. S. Parashar, J. Mater. Sci. Mater. Electron. 28, 15127 (2017).

27. A.A. Othman , Manar A. Ali , E.M.M. Ibrahim , M.A. Osman J. Alloys Compd. 683, 399 (2016).

28. H. Ohno, Science 281, 951 (1998).

29. G. A. Prinz, Science 282, 1660 (1998).

30. M.H. Huang, S. Mao, H. Feick, H. Yan, Y. Wu, H. Kind, E. Weber, R. Russo, P. Yang Science 292, 1897(2001).

31. J. M. D. Coey, M. Venkatesan, and C. B. Fitzgerald, Nat. Mater. 4, 173 (2005).

32. A. Ishizumi and Y. Kanemitsu, Appl. Phys. Lett. 86, 1 (2005).

33. Z. Zhou, T. Komori, M. Yoshino, M. Morinaga, N. Matsunami, A. Koizumi, and Y. Takeda, Appl. Phys. Lett. 86, 0 (2005).

34. J. M. Sun, W. Skorupa, T. Dekorsy, M. Helm, L. Rebohle, and T. Gebel, Appl. Phys. Lett. 85, 3387 (2004).

35. K. Potzger, S. Zhou, F. Eichhorn, M. Helm, W. Skorupa, A. Mücklich, J. Fassbender, T. Herrmannsdörfer, and A. Bianchi, J. Appl. Phys. 99, (2006).

36. S. H. Deng, M. Y. Duan, M. Xu, and L. He, Phys. B Condens. Matter 406, 2314 (2011).

37. J. Hays, K. M. Reddy, N. Y. Graces, M. H. Engelhard, V. Shutthanandan, M. Luo, C. Xu, N. C. Giles, C. Wang, S. Thevuthasan, and A. Punnoose, J. Phys. Condens. Matter 19, (2007).

38. M. A. Ciciliati, M. F. Silva, D. M. Fernandes, M. A. C. De Melo, A. A. W. Hechenleitner, and E. A. G. Pineda, Mater. Lett. 159, 84 (2015).

39. T. Das, B. K. Das, K. Parashar, and S. K. S. Parashar, Acta Phys. Pol. A 130, 1358 (2016)

40. X. Yan and G. Xu, Phys. B Condens. Matter 404, 2377 (2009).

41. X. Li, Y. Luo, and X. Liu, Adv. Mater. Sci. Eng. 2009, 0 (2009).

42. G. Ray, S.anjay Godara, M.K. Gupta, B. Kumar, Mater. Res. Bull. 59 267(2014).

43. M. H. Bezerra Junior, T. O. Abreu, F. F. do Carmo, J. E. V. de Morais, R. G. M. Oliveira, M. A. S. Silva, H. D. de Andrade, I. S. Queiroz Junior, J. C. M. Mota, A. S. B. Sombra, J Mater Sci: Mater Electron (2021) 
44. M. Pollak, T.H. Geballe, Phys. Rev. 122, 1742(1961).

45. P. Norouzzadeh, Kh. Mabhouti, M. M. Golzan , R. Naderali, J Mater Sci: Mater Electron 31, 7335-7347 (2020)

46. N. Kilınc, L. Arda, S. Oztürk, Z.Z. Oztürk, Cryst. Res. Technol. 45, 529(2010).

47. M. Chaari, A. Matoussi, Physica B 407, 3441(2012).

48. M. Ashokkumar, S. Muthukumaran, Opt. Mater.37, 671(2014).

49. S. Dey, S.K. Dey, B. Ghosh, V.R. Reddy and S. Kumar, Chem. Phys.138, 833(2013).

50. B. K Das, T. Das, K. Parashar and S K S Parashar, Appl. Sci. and Adv. Mater. Int. 2, 69 (2016).

51. S. Kumar, N. Tiwari, S.N. Jha, S. Chatterjee, D. Bhattacharyya, A.K. Ghosh, RSC Adv. 6, 107816 (2016).

52. R. Bhargava, P.K. Sharma, S. Kumar, A.C. Pandey, N. Kumar, J. Solid State Chem. 183, 1400(2010).

53. M. Mehedi Hassan, W. Khan, A. Azam, A.H. Naqvi, J. Ind. Eng. Chem. 21, 283(2015).

54. K. Sebayang, S. Taslima, M. Ginting, P. Sebayang, N. Bukit, Chem. Mater. Res. 9, 30(2017).

55. S.S. Sartiman, N.F. Djaja, R. Saleh, Mater. Sci. Appl., 2013, 528(2013).

56. V.D. Mote, World J. Condens. Matter Phys. 2, 208(2012).

57. S. Suwanboon, P. Amornpitoksuk, P. Bangrak, Ceram. Int. 37, 333(2011).

58. O. Altintaş Yildirim, C. Ceram. Int.42, 3229(2015).

59. N.F. Djaja, A. Noorhidayati, R. Saleh, AIP Conf. Proc. 1719, (2016).

60. I. Esparza, M. Paredes, R. Martinez, A. Gaona-Couto, G. Sanchez-Loredo, L.M. Flores-Velez, O. Dominguez, Mater. Sci. Appl. 2, 1584(2011).

61. O. Gürbüz, M. Okutan, Appl. Surf. Sci. 387, 1211(2016).

62. U. Ozgür, Y.I. Alivov, C. Liu, A. Teke, M.A. Reshchikov, S. Doğan, V. Avruti n, S.J. Cho, H. Morkọ, J. Appl. Phys. 98, 1-103(2005).

63. T. Pandiyarajan, B. Karthikeyan, J. Nanoparticle Res. 14, 647(2012).

64. R. John, R. John, R. Rajakumari, Nano Micro lett. 2, 65(2016).

65. W. Zhang, Z. Liu, Z. Liu, J. Zhao, Appl. Surf. Sci. 258, 6103 (2012).

66. X. Chu, S. Zhou, Y. Dong, W. Sun, X. Ge, Mater. Chem. Phys. 131, 27(2011).

67. K. Vojisavljević, M. Ćepanović, T. Srećković, M. Grujić-Brojin, Z. Branković, G. Branković, J. Phys. Condens. Matter. 20, 475202(2008).

68. S. Suwanboon, P. Amornpitoksuk, Ceram.Int.37, 3515 (2011).

69. T. Das, B.K. Das, K. Parashar, R. Kumar, H.K. Choudhary, A. V. Anupama, B. Sahoo, P.K. Sahoo, S.K.S. Parashar, Effect of Sr-doping on sinterability, morphology, structure, 
photocatalytic activity and AC conductivity of $\mathrm{ZnO}$ ceramics, J. Mater. Sci. Mater. Electron. 28 (2017) 13587-13595. 
Figures

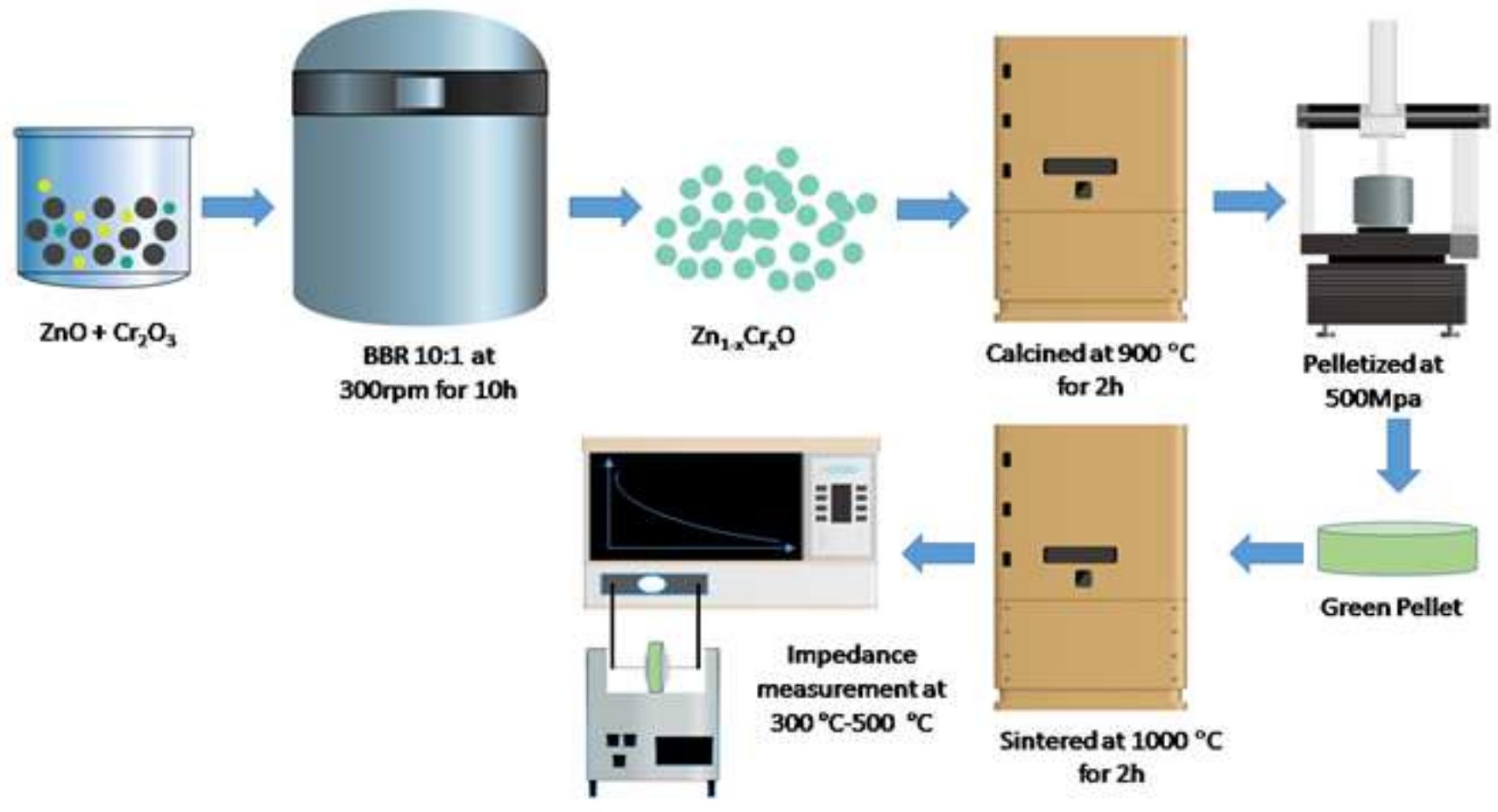

Figure 1

Figure 1

Schematic representation of methodology 

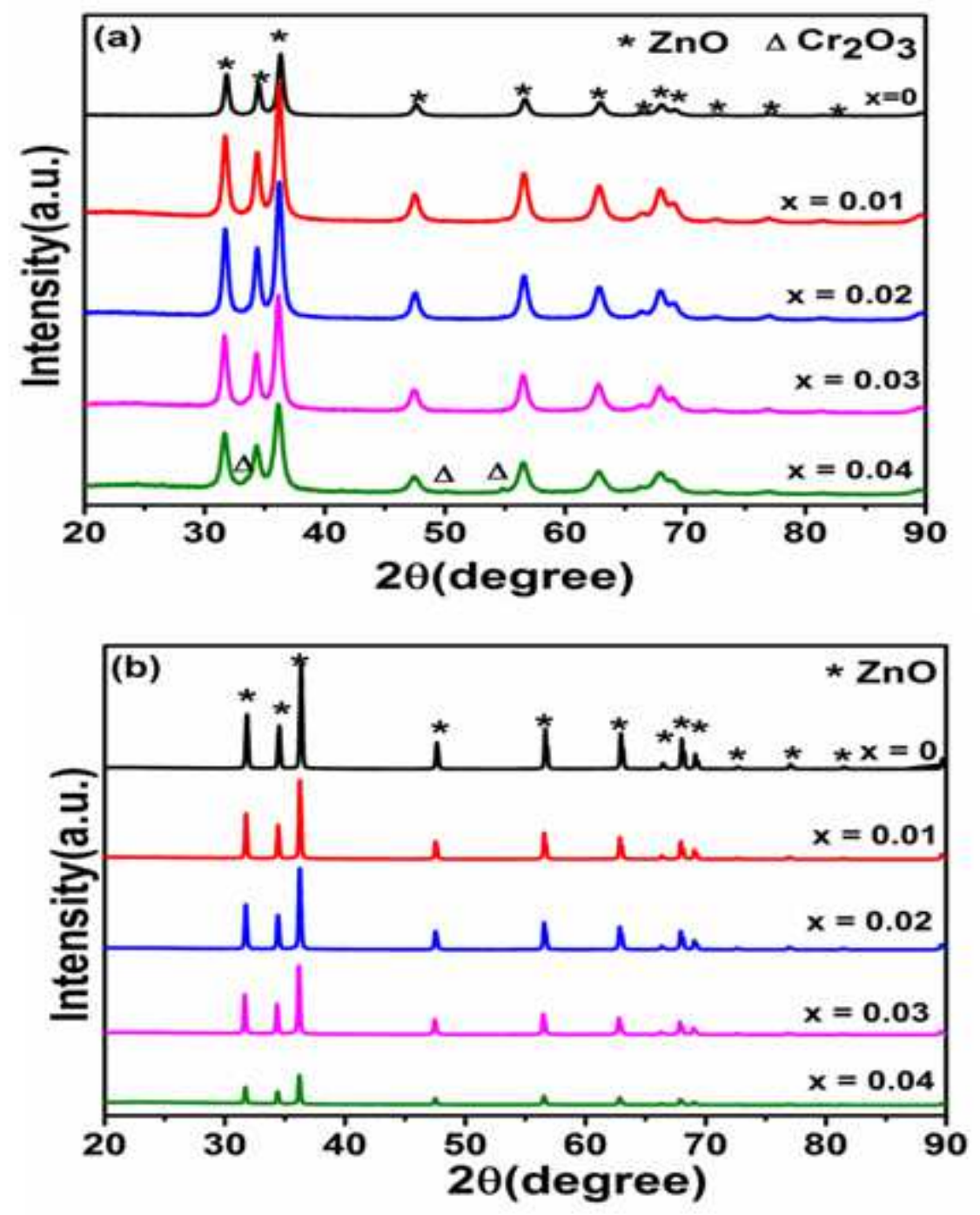

Figure 2

Figure 2

XRD pattern of Zn1-xCrxO ( $\mathrm{x}=0,0.01,0.02,0.03$, and 0.04$)$ nanoceramics (a) after ball milling for $10 \mathrm{~h}$ and (b) after ball milling for $10 \mathrm{~h}$ followed by calcination at $900^{\circ} \mathrm{C}$ for $2 \mathrm{~h}$. 

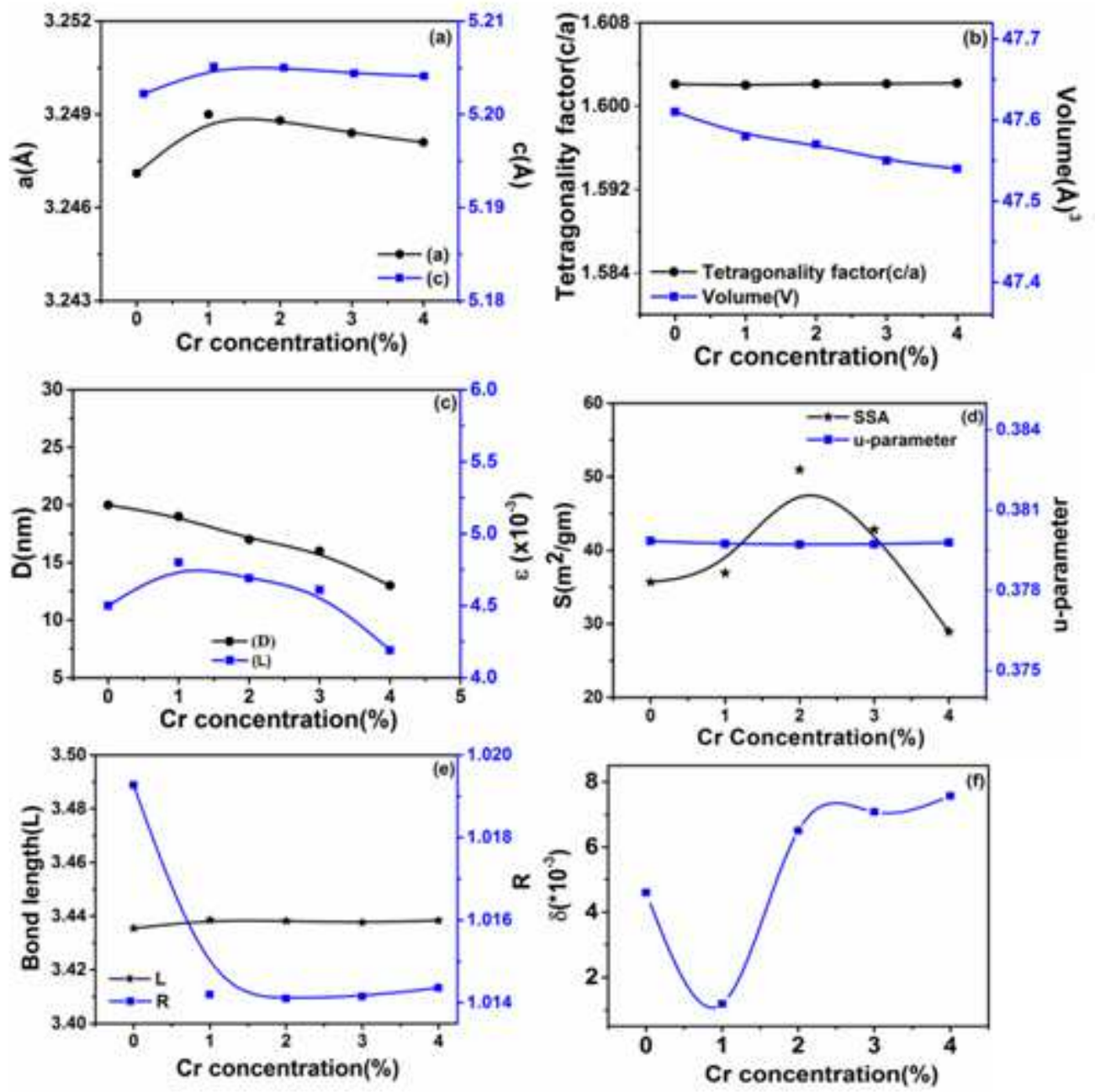

Figure 3

Figure 3

Variation of structural parameter with $\mathrm{Cr}$ concentration of $10 \mathrm{~h}$ ball milled $\mathrm{Zn} 1-\mathrm{xCrxO}(\mathrm{x}=0,0.01,0.02$, 0.03 and 0.04 ) nanoceramics (a) Latice pameter ' $a$ ' and ' $c$ ',(b) c/a ratio and volume (V), (c) crystallite size $(D)$ and strain $(\varepsilon),(d)$ specific surface area (S) and u-parameter (e) bond length $(L)$ and crystal lattice distortion degree $(\mathrm{R})$ and $(\mathrm{f})$ dislocation density $(\delta)$. 

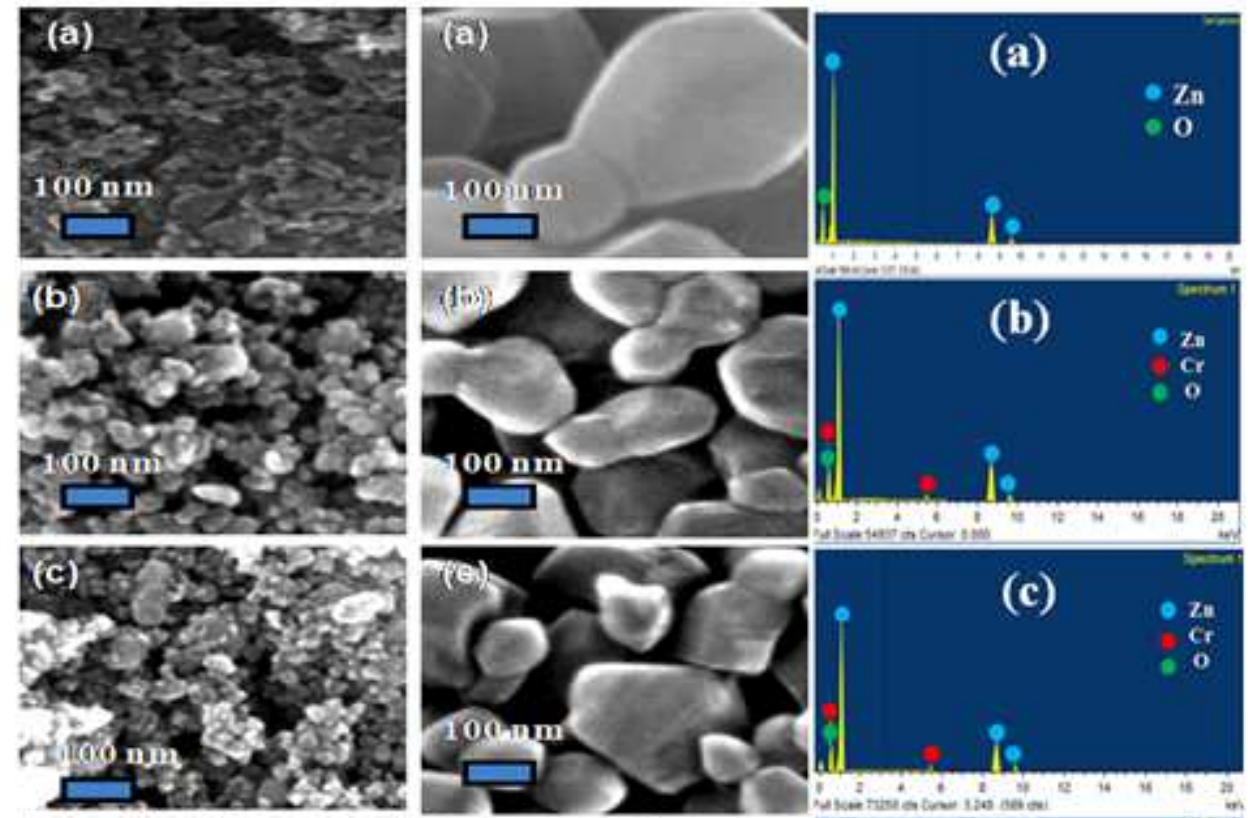

(d)
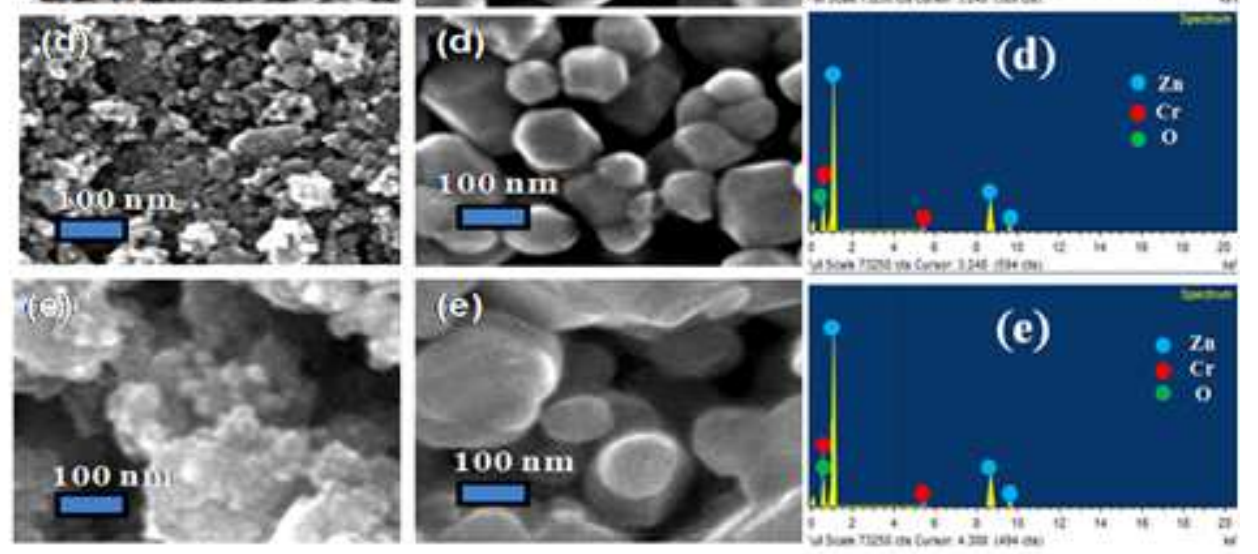

Figure 4

\section{Figure 4}

The FESEM micrograph of Zn1-xCrxO (a) $x=0$, (b) $x=0.01$, (c) $x=0.02$, (d) $x=0.03$ and (e) $x=0.04$ samples (i) $10 \mathrm{~h}$ milled uncalcined powder, and (ii) EDX of 10h milled Zn1-xCrxO samples. 

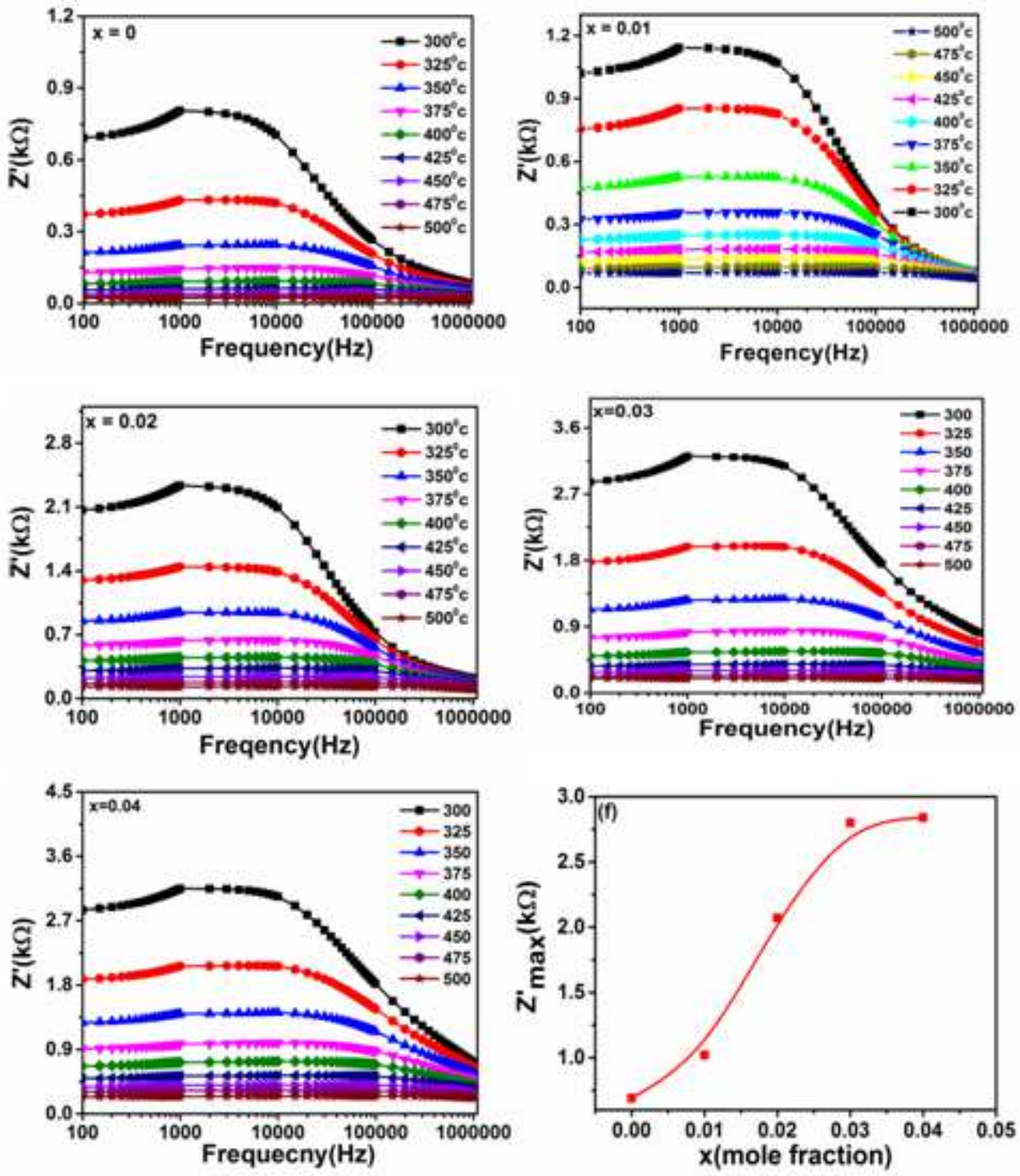

Figure 5

Figure 5

Variation of frequency with $\mathrm{Z}$ of the pellet sample prepared by the $10 \mathrm{~h}$ milled powder calcinated at $900{ }^{\circ} \mathrm{C}$ for $2 \mathrm{~h}$ and sintered at $1000^{\circ} \mathrm{C}$ for $2 \mathrm{~h}$ of $\mathrm{Zn} 1-\mathrm{xCrxO}(\mathrm{x}=0$ - 0.04) nanoceramics and (f) with different $\mathrm{Cr}$ concentration at a particular temperature $\left(300^{\circ} \mathrm{C}\right)$ and frequency $20 \mathrm{kHz}$. 

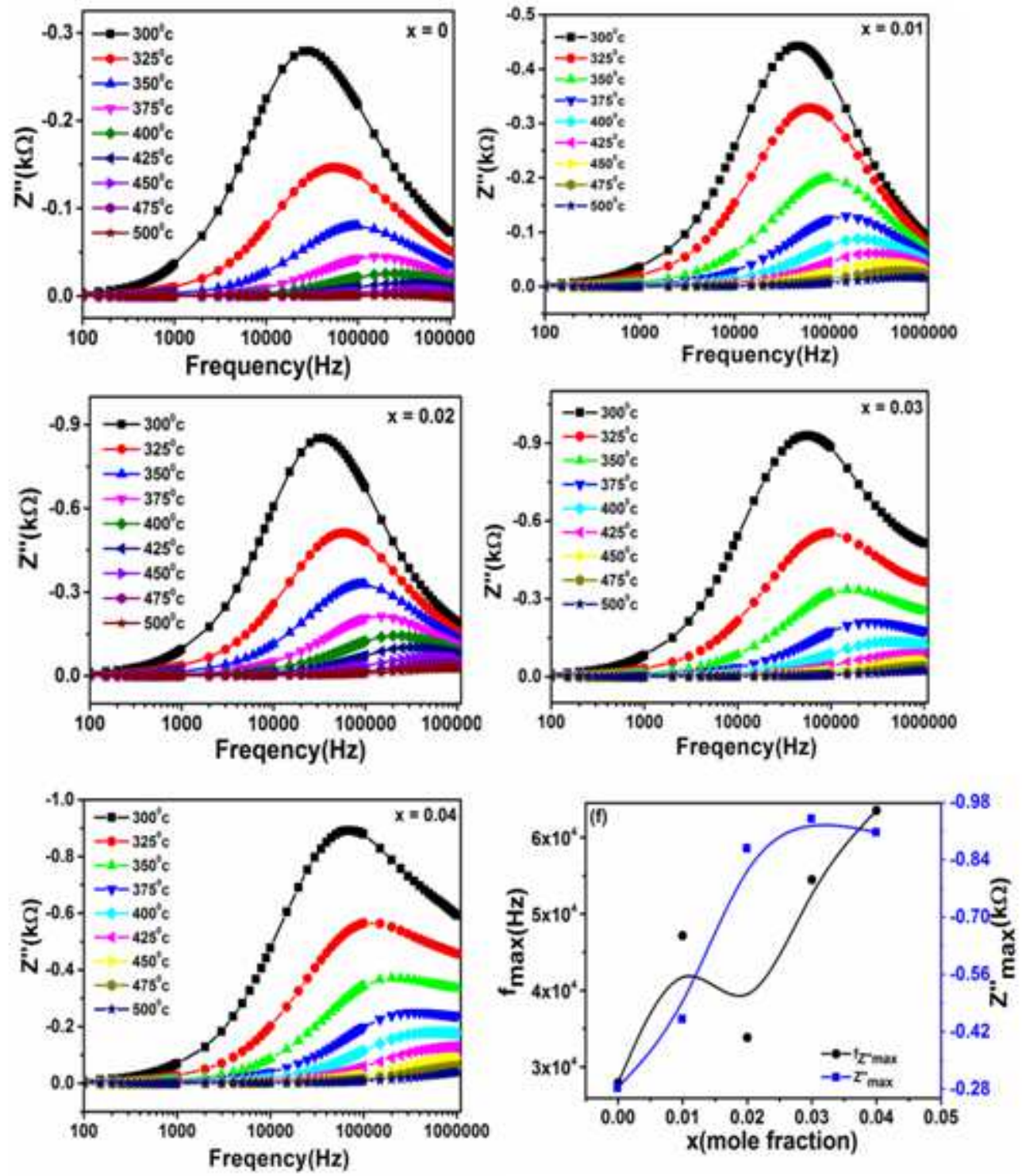

Figure 6

Figure 6

Variation of Z" with frequency of $\mathrm{Zn1-xCrxO}(\mathrm{x}=0$ - 0.04) of the pellet sample prepared from the $10 \mathrm{~h}$ milled powder calcinated at $900^{\circ} \mathrm{C}$ for $2 \mathrm{~h}$ with sintering at $1000^{\circ} \mathrm{C}$ for $2 \mathrm{~h}$ and $(\mathrm{f})$ Variation of fmax and Z"max with different $\mathrm{Cr}$ concentration at a particular temperature $\left(300^{\circ} \mathrm{C}\right)$ and frequency $20 \mathrm{kHz}$. 

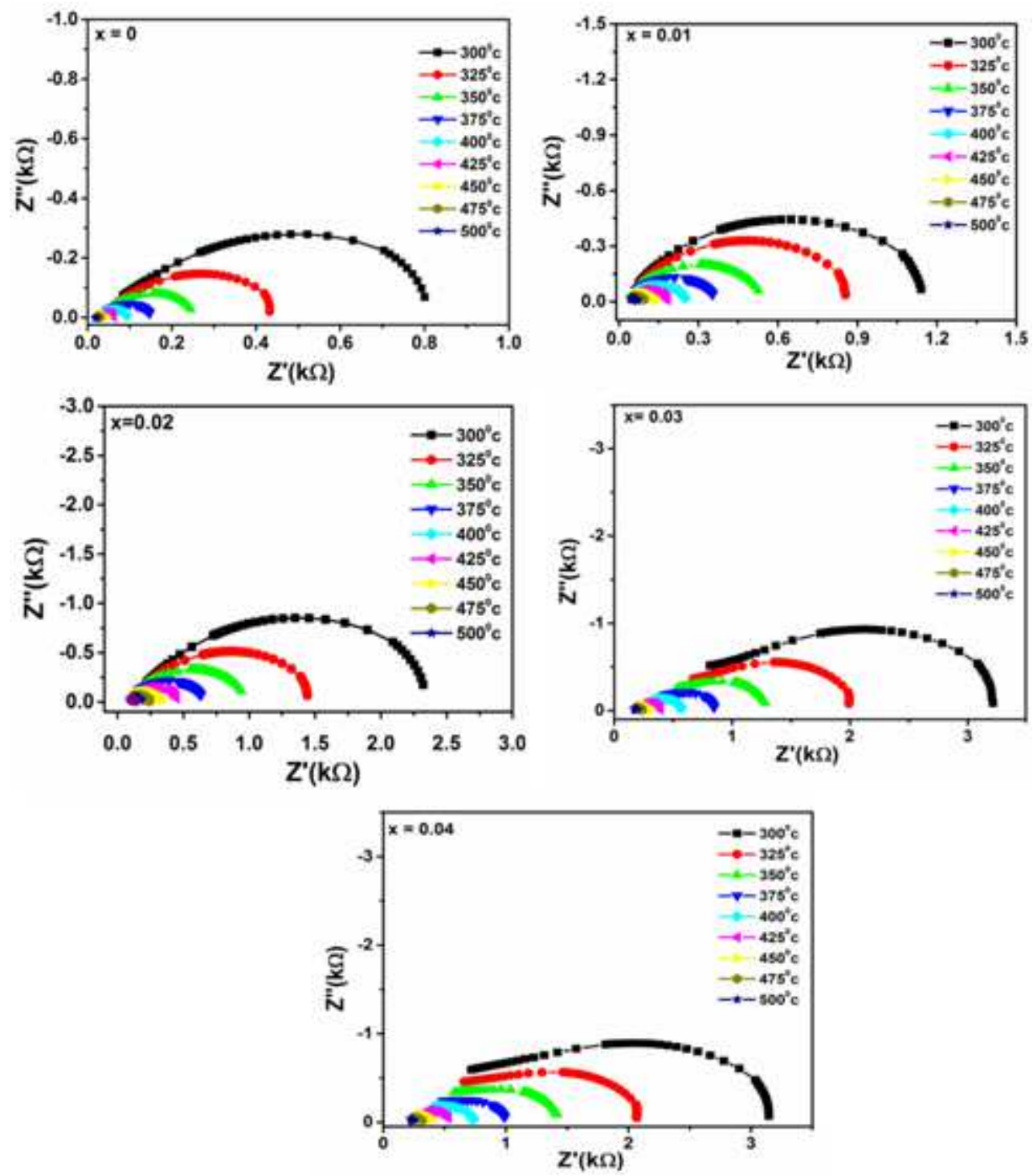

Figure 7

Figure 7

Z' vs Z" plot of Zn1-xCrxO (x = $0-0.04)$ nanoceramics.

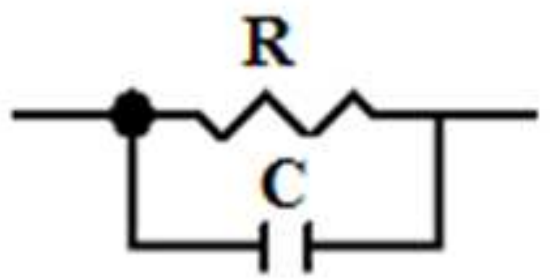

Figure 8

Figure 8 
Corresponding circuit diagram of $\mathrm{Cr}$ doped $\mathrm{ZnO}$ nanoceramics.

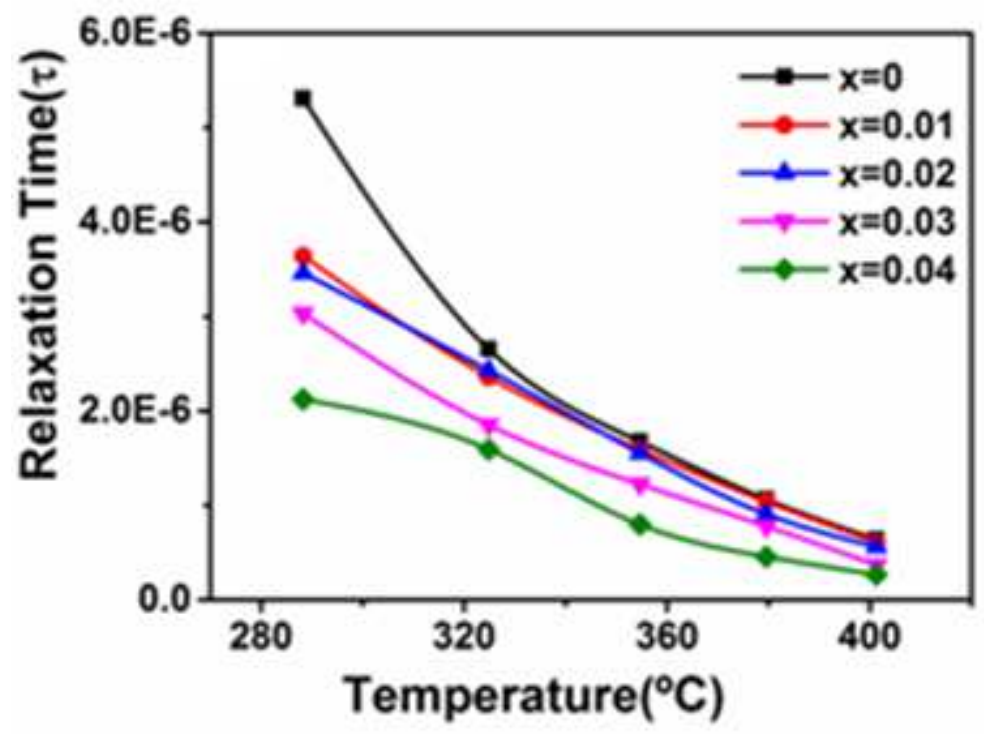

Figure 9

Figure 9

Variation of relaxation time $(\mathbb{\nabla})$ with inverse of temperature of $\mathrm{Zn} 1-\mathrm{xCrx}(\mathrm{x}=0,0.01,0.02,0.03$ and 0.04$)$ of the pellet samples prepared using the $10 \mathrm{~h}$ milled powders calcinated at $900^{\circ} \mathrm{C}$ for $2 \mathrm{~h}$ and sintered at $1000^{\circ} \mathrm{C}$ for $2 h$. 

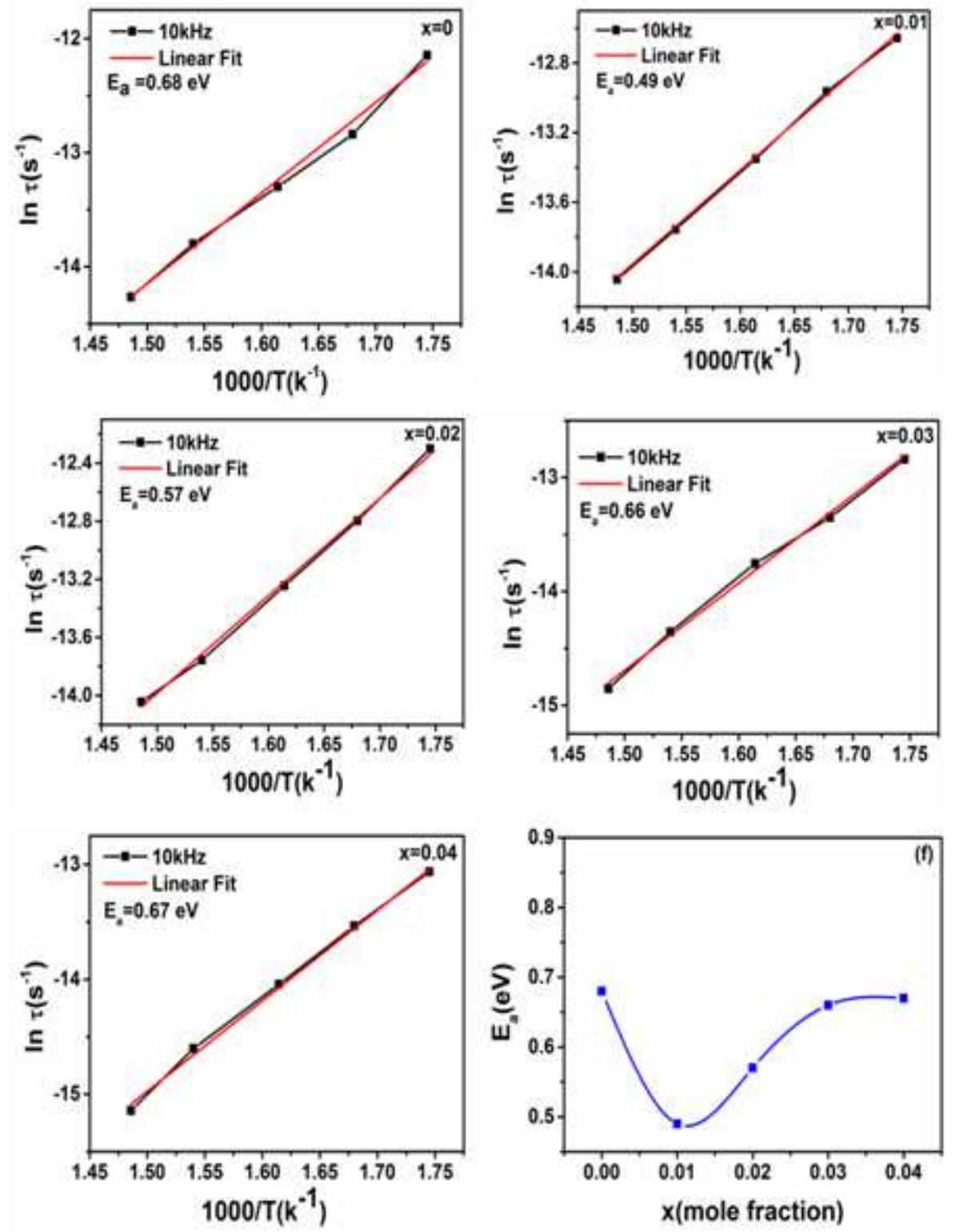

Figure 10

\section{Figure 10}

Variation of relaxation time ( $)$ with $103 / \mathrm{T}$ of $\mathrm{Zn} 1-\mathrm{xCrxO}(\mathrm{x}=0-0.04)$ nanoceramics (for impedance data) and (f) variation of Ea with Cr concentration. 